\begin{tabular}{|c|c|c|c|c|c|c|}
\hline \multirow{4}{*}{ Impact Factor: } & ISRA (India) & $=3.117$ & SIS (USA) & $=0.912$ & ICV (Poland) & $=6.630$ \\
\hline & ISI (Dubai, UAE & $=0.829$ & РИНЦ (Russia & $=0.156$ & PIF (India) & $=1.940$ \\
\hline & GIF (Australia) & $=0.564$ & ESJI (KZ) & $=8.716$ & IBI (India) & $=4.260$ \\
\hline & JIF & $=1.500$ & SJIF (Morocco & $=5.667$ & OAJI (USA) & $=0.350$ \\
\hline
\end{tabular}

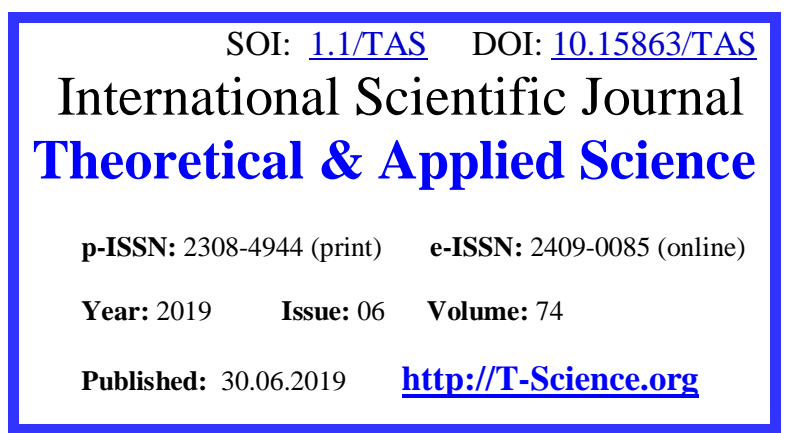

Section 33. Advertising technologies.

Creative. Innovations.

UDC685.34: 519.74

\section{QR - Issue}
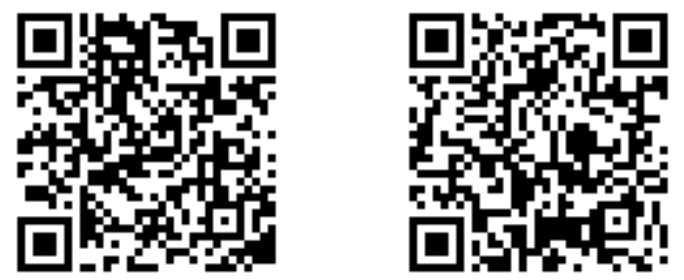

Artur Alexandrovich Blagorodov Institute of Entrepreneurship and Service sector (branch)

DSTU

bachelor, g. Shakhty blaghorodov@list.ru

Dmitri Olegovich Bordukh

Institute of Entrepreneurship and Service sector (branch)

DSTU

bachelor, g. Shakhty bordukh95@bk.ru

Angelina Vladimirovna Kopylova Institute of Entrepreneurship and Service sector (branch)

DSTU

bachelor, g. Shakhty angelinakopylova22121999@mail.ru

Vladimir Timofeevich Prokhorov ISOP (f) DGTU

Doctor of technical sciences, professor of the department "Designing, technology and design", Shakhty prohorov@sssu.ru

Natalia Vasilievna Tikhonova KNITU

Doctor of technical sciences, Professor of the Department "Design, clothing and footwear", g Kazan, Republic of Tatarstan prohorov@sssu.ru

\title{
THE VALUE OF LEARNING IN THE FORMATION OF THE LEADER ENTERPRISE OF COMPETENCE FOR THE PRODUCTION OF IMPORT-SUBSTITUTING PRODUCTS
}

Abstract: in the article the authors investigated the importance of learning for the formation of human behavior, able to manage the staff of the enterprise, to ensure satisfaction with the results of such work, to be passionate about it and become their face. For the successful management of the company's staff, studies were conducted to determine the degree of satisfaction of the person-leader with the results of the work of the enterprise's team with their work, i.e. to form workaholics. In this case, people who love to work and strive to work well and will be those who are able to implement together the entire team of the enterprise formulated before him tasks to ensure the production of importsubstituting products and guarantee the company a stable financial position.

Key words: specialization, standardization, performance, workaholics, the office, enterprise, enthusiasm, commitment, satisfaction, workload, salary, personality, identity, situation, compensation, risk, market, demand, competitiveness, products.

Language: English 


\begin{tabular}{|c|c|c|c|c|c|c|}
\hline \multirow{4}{*}{ Impact Factor: } & ISRA (India) & $=3.117$ & SIS (USA) & $=0.912$ & ICV (Poland) & $=6.630$ \\
\hline & ISI (Dubai, UAE & $=0.829$ & РИНЦ (Russia & $=0.156$ & PIF (India) & $=1.940$ \\
\hline & GIF (Australia) & $=0.564$ & ESJI (KZ) & $=8.716$ & IBI (India) & $=4.260$ \\
\hline & JIF & $=1.500$ & SJIF (Morocco & $=\mathbf{5 . 6 6 7}$ & OAJI (USA) & $=0.350$ \\
\hline
\end{tabular}

Citation: Blagorodov, A. A., Bordukh, D. O., Angelina, V. K., Prokhorov, V. T., \& Tikhonov, N. V. (2019). The value of learning in the formation of the leader enterprise of competence for the production of import-substituting products. ISJ Theoretical \& Applied Science, 06 (74), 7-36.

Soi: http://s-o-i.org/1.1/TAS-06-74-2 Doi: roskef https://dx.doi.org/10.15863/TAS.2019.06.74.2

\section{Introduction}

Are those resistant characteristics of his personality to the criterion based on human behavior, which determine the choice, decision-making about a person's behavior. Naturally, this kind of decisions have a major impact objectives pursued by the person, the conditions in which the action unfolds, its capabilities, the speaker of the processes, mood, and other factors. However, with all the diversity factors behavior of each individual has a certain stability and predictability, certain principles inherent behavior selection criteria and preferences, and the like taboo moments. Moreover, in exactly the same situation, if it exists at all, different people may take a completely different solutions. And it will again be determined by

Criterion base behavior of any person is made up of its location to the people, events and processes, together values shared by that person, a set of beliefs, which adheres to the people, and the principles he follows in his behavior. All these components of the base criterion of behavior are in close interaction, interpenetration and mutual influence. However, despite the strong interdependence, they can be regarded as relatively isolated characteristics of the human person, affecting his behavior.

\section{Main part}

Location of human people, individual processes, the environment, their work, the organization as a whole plays a very important role in the establishment of human and organizational environment of normal interaction. The same phenomenon or effect of having a completely identical manifestation and are the same, the impact on people, can cause different reactions due to the fact that people have a different arrangement of this phenomenon or action. Reflecting the feelings of a person in relation to a particular object, its location makes decisions and actions of the individual. It is important to emphasize that a person usually has a specific location for each object or phenomenon with which he faced in life.

Location is characterized by the fact that it is, first of all, invisibly, as signed in person. On the "surface" are only its consequences. Secondly, the arrangement stems from the feelings that feeds people to the subject. Thirdly, the location as it is a point located on the axis of the poles "like" - "do not like". Fourth, the location of the impact on human behavior and manifested in the fact that he behaves in accordance with the a priori positive or negative attitude to the phenomenon, object, process, or person.

Is it acceptable within the scientific analysis comparing the real object with the phenomenon of folk classics, for example, the market with fabulous
Aladdin's cave? To answer this question is not easy as thinking quite specialized, and specialty fixed in certain traditions, formalizing the approach. Scientific editing requires compliance with the characteristic mode of presentation of science content ideas. Neopositivists even tried to build a special language of scientific communication, however, to no avail. The collision was resolved in practice, by scientists themselves, most of whom are actively involved in scientific publications creative thinking, believing that thinking is a single stream of traffic concepts and images, logical and illogical, the real and the fantastic, imaginary. Cognition in any expression - the process forward, continuously connects the discrete, generally unusual. Normalized relative thinking, conventionally, organized artificially. Contacting scientific thinking, including its printed form, to the images created outside the scientific disciplines of knowledge, of course, due to the technology.

Thinking cannot exist outside of culture, it is the product of cultural progress. Multidirectional development of culture - the basis of its wealth and cultural contradictions of thinking dialectically united. Comparing the fabulous wealth of the cave with a wealth of development of the modern market, there is much to clarify how economic knowledge and the dynamics of the transformation of economic theory, in particular, to explain why the modern academic economists stubbornly distance themselves from political economics, contrasting the economic theory of classical economics.

Will, perseverance, resourcefulness provided Aladdin access to the wealth of the cave. No cobwebs are not able to stop the purposeful person. No unknowable, there is the unknown. Market - a complex economic mechanism, but it is possible to understand and take control. Wealth of the cave belonged to the rapists, the market is also not free from violence, so the state is obliged to take the necessary measures to curb market forces serving fertile ground for those who prefer the force of law. Unlike the indigenous cave resources and the market that the robbers did not intend anything else to add, and Aladdin had to be content received. Wealth same market, by contrast, will grow, and with them the problems, chief among them the implementation of commodity revenues. What should be the product the buyer swept it off the shelves? What the buyer would like to see on the market?

If the "buyer" is to consider the socio-economic context, the answer to the second question seems perfectly clear. The market is waiting for a buyer with high purchasing power. Such buyers in Russia is, however, their share does not exceed 7 percent, and 


\begin{tabular}{|c|c|c|c|c|c|c|}
\hline \multirow{4}{*}{ Impact Factor: } & ISRA (India) & $=3.117$ & SIS (USA) & $=0.912$ & ICV (Poland) & $=6.630$ \\
\hline & ISI (Dubai, UAI & $=0.829$ & РИНЦ (Russia & $=0.156$ & PIF (India) & $=1.940$ \\
\hline & GIF (Australia) & $=0.564$ & ESJI (KZ) & $=8.716$ & IBI (India) & $=4.260$ \\
\hline & JIF & $=1.500$ & SJIF (Morocco & $=5.667$ & OAJI (USA) & $=0.350$ \\
\hline
\end{tabular}

familiar to the mass market, they rarely go, more by accident than by necessity. The mass consumer is extremely economical and "shake" it to purchase hard. This requires a certain type of product that can fascinate and supply of goods, - 'cultural Packed ". It is necessary to attract a buyer, mesmerized. As a reflection of the desire to understand the specifics of the market demand for the status of the goods must be considered a revival of interest in the concept of "the attractiveness of the product." It is significantly more specific in content in comparison with the close and more pseudoscientific concept of "demand for the goods market."

The concept of "attractiveness of the product" is specified in the characteristics of the goods at the same time its use value - the degree of "exchange" for the money and the realism of the price set by the seller. With the concept of "attractiveness" facing in the direction of the vector of the buyer, we have to be friends, and the manufacturer and the seller. It connects node interests of all major stakeholders economically free market. This function "attractiveness" explains the active promotion of the concept of the group of those economic categories that reveal the potential competitiveness of the product on the market. This extension of the individual authors tend to be treated as a traditional action for the application of the advertising production, which makes it impractical because of the one-sidedness, hinder the achievement of a systemic understanding of the value of the goods in the appeal process of reproduction. Advertising production is really present here, but as an accompanying factor, that is confirmed by the usual place of advertising in the market.

Increasing interest in scientific research and economic policy to the concept of "attractiveness of goods", in our opinion, shows the pattern of mass production restructuring with the existing simplified type to new, sometimes up against it, the organization - lean production (the zealous, sparing production), focused not on abstract manifold needs of customers, and to the specific architecture of consumer needs and the solvency of potential buyers. Economic science call through market research architecture to become a direct productive force, objectified in this way, the main consequence of the scientific and technological revolution the middle XX century.

History of market allocation of goods in the area of special attention of economists and sociologists is associated with the birth and development of mass production. The mass factory production is calculated from the Industrial Revolution, which laid the scientific, technical and organizational prerequisites for such a development in productivity, which was enough for a real opportunity to meet the demand for vitally important goods of the general population through the provision of work and steady pay for work. It's a combination of production and consumption has launched the development of reproduction in national and then transnational scale.

Preceded the Industrial Phase subsistence farming does not fully conform to the concept of "reproduction", it is determined by the local demand for manufactured product and was essentially closed to the manufacturer, are not contributing to a proper degree of national progress. Hence the cult of aggressive wars aimed at robbery near and distant neighbors, feudal fragmentation, the permanent redistribution of property. War and military actions performed function of the market. The market has worked, in addition to politics, was not permanent.

It is also appropriate to emphasize that the development of the market and the formation of which has become a classic image reproduction must not only scientific and technological progress, changing the mode of organization of production, but also the competitive production of products on the market, the market structure differentiation. In the history of the market can see the dialectical law of the relationship of quantitative and qualitative changes. When the manufacturer started to work on the market, the product has become a commodity. Change product status changed and the requirements for it. That the product has been implemented as intended, he had to attract the attention of the buyer. This product - is not a product for sale, and the product that can interest the consumer. The term "top seller" reflects precisely the movement of goods, its demand for the buyer. "Hot Categories" - Market locomotives.

"Attractiveness" sign and belongs to the basic characteristics of the product, and is a "relic" of his property, to strengthen its position. Unappealing merchandise produce unprofessional absurd. Pets could get accustom to consume that have prepared, grown or manufactured, as buyers have always a reason and vote coin, so necessary for the continuation of production.

In recent times a synonym for "attractiveness" the notion of "trade dress." Hence, perhaps, went the expression "a prominent item", her the one that accumulates the attention, "rushes" in the eye. The ability to make a product "prominent", "attractive" and requires from the manufacturer and seller of high qualifications, fantasy, presentation skills. The thing is expensive, but the cost of paying off the result. The demand for "attractive", "prominent" product high speeds to obtain working capital, stimulates the growth of production, consolidates seller relationship with the manufacturer, gives increase sustainability of production that serves as a good advertisement for the manufacturer on the market, eliminating the part of the direct payment of advertising services, costing all more expensive because of its pretentiousness.

The panoramic and historical overview of the system situation "attractiveness" of the concept proves its versatility and complexity of the manifestations. The fact that the term "attraction" is not as common in 


\begin{tabular}{|c|c|c|c|c|c|c|}
\hline \multirow{4}{*}{ Impact Factor: } & ISRA (India) & $=3.117$ & SIS (USA) & $=0.912$ & ICV (Poland) & $=6.630$ \\
\hline & ISI (Dubai, UAI & $=0.829$ & РИНЦ (Russia & $=0.156$ & PIF (India) & $=1.940$ \\
\hline & GIF (Australia) & $=0.564$ & ESJI (KZ) & $=8.716$ & IBI (India) & $=4.260$ \\
\hline & JIF & $=1.500$ & SJIF (Morocco & $=5.667$ & OAJI (USA) & $=0.350$ \\
\hline
\end{tabular}

journal publications, should not enter the consciousness in the state of the question about the real significance of this trait in the marketability of the ongoing economic restructuring on the level of lean production. Not by chance, answering the question, "Levada-center" set in April 2017: "What particularly inspires you a sense of pride in Russia?", 1600 citizens of 137 communities 'economic success' destinations in 48 regions of the Russian Federation put on the penultimate place, giving the latter "relative" - "the health care system."

Marx began to study the bourgeois mode of production with an analysis of the contradictory nature of the goods. This product is characterized by an objective of consumer and exchange value. The first determines the demand in the market, the second - a measure of demand. The cost of objectified labor costs - the amount and quality of work produced. Labor is also evident through the contradiction born commodity essence of capitalist reproduction. On the one hand, it is creative, the creative power of the human - side of his nature, on the other hand, it is a necessity to alienate the human essence, because the product of labor, which absorbed the creative force, made for someone else's use. Marxism deduces from the theory of social alienation deadlock development of bourgeois society. In his main work K. Marx developed not only the theory of capitalist development, it was important to him to bring to the working mode of the dialectical materialist method of scientific analysis. The dialectic of Hegel was local. Hegel has restricted the dialectical development of the spirit of the movement. Marx saw in the dialectic of the universal way of development, so in "Capital" thoroughly followed the dialectic of production, with an emphasis on the material nature of the goods produced by labor. Product quality is created contradictory nature of the goods and is manifested through its relationship in the form of essential features. Dialectical materialism is based on the recognition of tangible goods. Intangible goods - a kind of semi-finished goods, "transitional form" to the practical expression of materialization. However, the specific material goods. it was important to bring to the working mode of the dialectical materialist method of scientific analysis. The dialectic of Hegel was local. Hegel has restricted the dialectical development of the spirit of the movement. Marx saw in the dialectic of the universal way of development, so in "Capital" thoroughly followed the dialectic of production, with an emphasis on the material nature of the goods produced by labor. Product quality is created contradictory nature of the goods and is manifested through its relationship in the form of essential features. Dialectical materialism is based on the recognition of tangible goods. Intangible goods - a kind of semi-finished goods, "transitional form" to the practical expression of materialization. However, the specific material goods. it was important to bring to the working mode of the dialectical materialist method of scientific analysis. The dialectic of Hegel was local. Hegel has restricted the dialectical development of the spirit of the movement. Marx saw in the dialectic of the universal way of development, so in "Capital" thoroughly followed the dialectic of production, with an emphasis on the material nature of the goods produced by labor. Product quality is created contradictory nature of the goods and is manifested through its relationship in the form of essential features. Dialectical materialism is based on the recognition of tangible goods. Intangible goods - a kind of semi-finished goods, "transitional form" to the practical expression of materialization. However, the specific material goods. Hegel has restricted the dialectical development of the spirit of the movement. Marx saw in the dialectic of the universal way of development, so in "Capital" thoroughly followed the dialectic of production, with an emphasis on the material nature of the goods produced by labor. Product quality is created contradictory nature of the goods and is manifested through its relationship in the form of essential features. Dialectical materialism is based on the recognition of tangible goods. Intangible goods - a kind of semi-finished goods, "transitional form" to the practical expression of materialization. However, the specific material goods. Hegel has restricted the dialectical development of the spirit of the movement. Marx saw in the dialectic of the universal way of development, so in "Capital" thoroughly followed the dialectic of production, with an emphasis on the material nature of the goods produced by labor. Product quality is created contradictory nature of the goods and is manifested through its relationship in the form of essential features. Dialectical materialism is based on the recognition of tangible goods. Intangible goods - a kind of semi-finished goods, "transitional form" to the practical expression of materialization. However, the specific material goods. Product quality is created contradictory nature of the goods and is manifested through its relationship in the form of essential features. Dialectical materialism is based on the recognition of tangible goods. Intangible goods - a kind of semi-finished goods, "transitional form" to the practical expression of materialization. However, the specific material goods. Product quality is created contradictory nature of the goods and is manifested through its relationship in the form of essential features. Dialectical materialism is based on the recognition of tangible goods. Intangible goods - a kind of semi-finished goods, "transitional form" to the practical expression of materialization. However, the specific material goods.

The quality of natural phenomena really the identity of their material nature, but the goods, even in its final form and material, there is something different from the created outside and independent of human existence. Work in the product materializes 


\begin{tabular}{|c|c|c|c|c|c|c|}
\hline \multirow{4}{*}{ Impact Factor: } & ISRA (India) & $=3.117$ & SIS (USA) & $=0.912$ & ICV (Poland) & $=6.630$ \\
\hline & ISI (Dubai, UAE & $=0.829$ & РИНЦ (Russia & $=0.156$ & PIF (India) & $=1.940$ \\
\hline & GIF (Australia) & $=0.564$ & ESJI (KZ) & $=8.716$ & IBI (India) & $=4.260$ \\
\hline & JIF & $=1.500$ & SJIF (Morocce & $=5.667$ & OAJI (USA) & $=0.350$ \\
\hline
\end{tabular}

reasonable nature of man - feelings, thoughts and ideals. The product is expressed by the wisdom of the human reality, hence the notion of "quality of goods" must be embodied human spirituality, confirming that the product created by man for man. In our opinion, the market quality of the product is intended to reveal the unity of value through a combination of natural and artificial nature of the material of its transformation of human creative activity. The quality of the product, along with the functionality that is defined by its attractiveness.

Attractiveness - a highly important factor in pricing. Part of the price, dependent on the attractiveness, can be considered as the economic equivalent of appeal. Measured by the size of this part of the demand. Receipt of goods with new features expensive and limited physical nature. This way to surprise the consumer runs the risk of loss of competitiveness due to the high cost. Easier and more promising to manipulate the mind. To do this, there are ready-made psychological mechanisms and the necessary scientific knowledge. If the item is in its form has not made the proper impression, not caught, it can be made attractive by modulating in a particular context, for example, acting on the psyche of subcultural perception. How many of us pop "stars" without proper voice and vocal culture. Little of, they attract their performing "skill", with them trying to copy the clothes, accessories, shoes. They form the taste of certain social groups, indirectly affecting the market position of goods. No data to enter the public schools and universities of the arts, go to the "Star Factory".

"The appeal" has the reserves, which the managers are still very unprofessional performance. There is no doubt that in the future, marketers will extend beyond the current range of a particular form of knowledge and will press control production range. market management will claim not as nowadays, the teachings of Freud about "it", "ego" and the conditions to achieve "super-ego"; theory of the "collective unconscious," Jung; Erich Fromm ideas about the importance of awareness for the ability to be surprised, and the role of dreams in real life.

Market and production prospects are connected with the activity, which will show the control in relation to the concept of "attractiveness of the product." The hardest part, formed a paradigm of minimizing costs for them will be the restructuring process of thinking with a utilitarian, pragmatic warehouse for the final margin, on a new principle: to obtain legally and morally the maximum margin. All energetic going into the mathematical methodology, economists lose their specificity political economy analysis, required to act against the background of prospects. Most often you need to go back to the classics - William Petty, Adam Smith, David Ricardo. "Classics" figuring in the present, thinking about the future, correctly believing that science is limited by the current course of events it reminds anchored ship built as a means of movement. "Fathers" economic science "were philosophers,

Economists can understand. Given the instability of world development to look ahead beyond the next corner is extremely dangerous. The crisis of 2008, the consequences of which are still forced to storm the world economy - it is man-made. Way paved Nobel laureates, like the best. It turned out, as always. Economic science, it is time to return to the scale of thinking - not only space, but time. Studies of this, spending a stepping stone for the reasonably foreseeable future, complex them with related sciences, including the teaching of VI Vernadsky's noosphere. E. Deming back in the 1950 s by developing the philosophical foundation of quality management, in the "seven deadly diseases" in the first place put the plan is not focused on the production of such goods and services that the market demands, The American expert aware of the complexity of the situation. [2]

Lack of sufficient management is elaborated the concept of "the attractiveness of the product" is reminiscent of his philological roots, the interpretation of "attractiveness" in the classical sources. IN AND. Dal "attract" is identified with "pull", he emphasized the physical sense of the term, overshadowing the physiological and psychological side attraction "draw moral, feeling the power of persuasion ..., enticing, attract, captivate." [3, p.403] F.A. Brockhaus and I.A. Efron was not included in his collection of the term. I bypassed it and Britannica, which is hard to justify taking into account the willingness of the publication to make the text changes occurring in the world.

A detailed analysis of the content of the concept can be found in a four academic dictionary of Russian language. "Attractive, attractive, interesting .. that has to itself, stimulates, awakens curiosity" [4, p.542]. Continuing the argument about the appeal, we will come to a sign of "originality". Normally it with originality, its concreteness, exciting interest in the phenomenon, linked the attractiveness of the goods, which is generally consistent with the concept. At the same time, we must try not to an absolute position of the "attractiveness" in the commodity market.

The fate of his demand for goods is determined by the market. "Demand" - the concept of social and humanitarian level. It is due, on the one hand, the degree of development of society and the solvency of the mass consumer, on the other - the structure of the customer's needs. Epicurus differentiated requirements on the basis of two features - a natural and necessary. According to the presentation of the ancient thinker, needs are divided into three types: "natural and necessary", "natural and necessary" and "unnatural and not appropriate." [5, p.403, 469]

The opinions of Epicurus there is a hint to understanding the status of the goods. There are 


\begin{tabular}{|c|c|c|c|c|c|c|}
\hline \multirow{4}{*}{ Impact Factor: } & ISRA (India) & $=3.117$ & SIS (USA) & $=0.912$ & ICV (Poland) & $=6.630$ \\
\hline & ISI (Dubai, UAE & $=0.829$ & РИНЦ (Russia & $=0.156$ & PIF (India) & $=1.940$ \\
\hline & GIF (Australia) & $=0.564$ & ESJI (KZ) & $=8.716$ & IBI (India) & $=4.260$ \\
\hline & JIF & $=1.500$ & SJIF (Morocce & $=5.667$ & OAJI (USA) & $=0.350$ \\
\hline
\end{tabular}

products is objectively necessary, they must be natural born they need. The buyer is obliged to buy such products - they are a necessary condition for its survival. Of course it is desirable that the goods that make up the "basket of existence" of the consumer, were not only useful to the necessary, but also pleasant on sensations, but not to purchase such products is permitted only in two cases, when there is nothing to pay and there is nothing to change.

Naturally, the necessary goods - "running" in the market always. If they are delayed in warehouses or in the point of sale, then only one reason - lack of access pricing, greedy speculators, occupying the market. Shoes - a typical representative of the group of naturally-needed goods, along with clothes and household utensils. The main function of the shoe lies in its ability to protect the lower limbs of the mechanical and thermal damage. Shoe design regulates mainly its functional accessory. Aesthetic design side is built on the basis function. A characteristic feature of modern halls shoe shops are different kinds of events, aimed ostensibly to reduce prices. When the third pair promise to give free trade institutions, which means that the price of the first and the second allows you to safely compensate for the loss, related to "gift". They pay the price of their "gift". More obvious argument in favor of the definition of the situation with pricing as a one-way non-existent. Oil and gas companies lay in pricing the cost of exploration in difficult, often extreme circumstances, requires special equipment, specialized materials. Unknown and untapped involve high risk, unpredictable scientific and technical losses. Everyone understands that there is a speculative approach, a priori overstate the loss of product production, but the lack of perfectly developed methods for calculating the inevitable investments in design; the level of scientific and technical support, the need for risky actions, significantly soften critical reaction. More obvious argument in favor of the definition of the situation with pricing as a one-way non-existent. Oil and gas companies lay in pricing the cost of exploration in difficult, often extreme circumstances, requires special equipment, specialized materials. Unknown and untapped involve high risk, unpredictable scientific and technical losses. Everyone understands that there is a speculative approach, a priori overstate the loss of product production, but the lack of perfectly developed methods for calculating the inevitable investments in design; the level of scientific and technical support, the need for risky actions, significantly soften critical reaction. More obvious argument in favor of the definition of the situation with pricing as a one-way non-existent. Oil and gas companies lay in pricing the cost of exploration in difficult, often extreme circumstances, requires special equipment, specialized materials. Unknown and untapped involve high risk, unpredictable scientific and technical losses.
Everyone understands that there is a speculative approach, a priori overstate the loss of product production, but the lack of perfectly developed methods for calculating the inevitable investments in design; the level of scientific and technical support, the need for risky actions, significantly soften critical reaction. Oil and gas companies lay in pricing the cost of exploration in difficult, often extreme circumstances, requires special equipment, specialized materials. Unknown and untapped involve high risk, unpredictable scientific and technical losses. Everyone understands that there is a speculative approach, a priori overstate the loss of product production, but the lack of perfectly developed methods for calculating the inevitable investments in design; the level of scientific and technical support, the need for risky actions, significantly soften critical reaction. Oil and gas companies lay in pricing the cost of exploration in difficult, often extreme circumstances, requires special equipment, specialized materials. Unknown and untapped involve high risk, unpredictable scientific and technical losses. Everyone understands that there is a speculative approach, a priori overstate the loss of product production, but the lack of perfectly developed methods for calculating the inevitable investments in design; the level of scientific and technical support, the need for risky actions, significantly soften critical reaction. unpredictable scientific and technical losses. Everyone understands that there is a speculative approach, a priori overstate the loss of product production, but the lack of perfectly developed methods for calculating the inevitable investments in design; the level of scientific and technical support, the need for risky actions, significantly soften critical reaction. unpredictable scientific and technical losses. Everyone understands that there is a speculative approach, a priori overstate the loss of product production, but the lack of perfectly developed methods for calculating the inevitable investments in design; the level of scientific and technical support, the need for risky actions, significantly soften critical reaction.

"In war as in war," he called the writer-soldier, was burning in a self-propelled gun, his famous novel, extrapolating his approach, repeat the following: "In a market like the market." Set free market relations between the producer of the goods, the consumerbuyer and the seller, the intermediary, the government eased life for themselves and it is not excluded, made it comfortably at the expense of producers and consumers. Pricing in a market economy involves objective factors such as the cost of the goods, the consumer interest in the buyer him, effective demand and payment Seller's participation. But we are talking about proportional complicity. Strength of market factors can not be calculated according to the formulas that describe the forces in the mechanical movement, the parallelogram of forces is not available here, 


\begin{tabular}{|c|c|c|c|c|c|c|}
\hline \multirow{4}{*}{ Impact Factor: } & ISRA (India) & $=3.117$ & SIS (USA) & $=0.912$ & ICV (Poland) & $=6.630$ \\
\hline & ISI (Dubai, UAI & $=0.829$ & РИНЦ (Russia & $=0.156$ & PIF (India) & $=1.940$ \\
\hline & GIF (Australia) & $=0.564$ & ESJI (KZ) & $=8.716$ & IBI (India) & $=4.260$ \\
\hline & JIF & $=1.500$ & SJIF (Morocco & $=5.667$ & OAJI (USA) & $=0.350$ \\
\hline
\end{tabular}

however, the proportionality of participation in the formation of the final price you can get with a given degree of accuracy. And it was high time to carry out this operation, to politically and economically to decide where the border of the civilized market and bazaar, built "on concepts."

For what and whose market freedom fighting liberals - politicians, why distorting market pricing treated as a natural development costs, normal for democratic governance? Why not combine the empty shelves of the Soviet time stores queues? That there is no contrast with boarded shelves of stores and lack of current customers? The deficit was really up to the 1990 s, but it was associated primarily with high purchasing power, affordability of most goods. Demand outstripped production. Now, on the other hand, salespeople are clearly superior to the real possibilities of buyers that has hurt domestic producers and, as bringing peddling cheap goods that are hazardous to health.

As a consequence, once the political and economic imbalances booming loans, creating the illusion of purchasing power. Russian consumer driven economic policies in the financial trap. The essence of the situation is not in economic literacy of the population, and in the worldview primitivism enforcers everywhere and aggressively. Students are taught to memorize, students are not taught to think scientifically, calling it the modernization of education. Life has the ability to act effectively on the basis of real possibilities. The substitution of the existing reality, really earned, to virtual and subject, life on loan, inevitably leads to spiritual nihilism, moral decay and crisis of identity.

The primary reasons for the one-dimensionality of the individual consumer must be sought in the aligned civilized anarchy of the commodity market. What's next? The answer must be sought in the same place, that is where all with the need to meet - in the market. Economic policy priorities designed to determine the role of the market: he made the fraternal burial native producers or trigger recovery of domestic production? But the manufacturers do not have to contemplate what is happening, to criticize politicians and claim for themselves favorable conditions for development. They with their status in the society faced with a necessity to find new promotion factors to think about the reserves, not yet involved in the process.

In Comte's plan that every science should be a philosophy, not all false. Philosophers who adhere to the classical concepts of philosophy, arguing with Comte, except to give erroneous methodology and, especially, at the mercy of world private science reflection. The dissolution of philosophical reflection in scientific knowledge in recent initiate epistemological impasse as trigger absolutization in solving universal problems of scientific knowledge. The adoption of generalizing and guide decisions in the knowledge - the lot regardless of the specifics of private judgment "judges". At the same time, the Comte was certainly right in thinking that only unpolluted stereotypes of thinking can operate efficiently, be innovative, innovative, creative. Anyone who moved into the path of business development organizations, such as prayer №1 «Our Father" should know and repeat: Only dialectical thinking will help me to be successful, will save the company. But who learned to think dialectically in our years? Russian democrats, manage at the end of XX century politics, dialectic identified with the directives and slogans of the Soviet era, and deliberately cut off her democratic roots as vigorously as uprooted vineyards Massandra improvised MS Gorbachev, and even earlier shag builders of communism where it should not have done, according to the instructions of voluntarist NS Khrushchev. like uprooted vineyards Massandra improvised MS Gorbachev, and even earlier shag builders of communism where it should not have done, according to the instructions of voluntarist NS Khrushchev. like uprooted vineyards Massandra improvised MS Gorbachev, and even earlier shag builders of communism where it should not have done, according to the instructions of voluntarist NS Khrushchev.

The initiative is due to the entrepreneur in deciding the status and trends of the existing market. But dialectically organized thinking does not allow him to develop a business plan, calculated for the foreseeable future, be in the grip of market conditions. No matter how arbitrarily formed, anarchic free market was not, it regulates the production of motion. All in manufacturing due common node. "All are one," says the ancient dialectic, and were looking for something that makes everything uniform. Today, the market requires one, tomorrow it will be the situation on the other, however, we cannot exclude a repetition of today. Therefore, pre-need, comprehensive and better systemic approach. The system is better because it allows you to join the essence of what is happening, involves the allocation of system-forming factor. A factor which the economic analysis of the market and production was to be a commodity. It is no accident Marx in "Capital" began with the goods, called it the economic cell of the body and build capitalism from the contradictory nature of the commodity mode of production contradictions of bourgeois movement.

Compete in the market rather than the goods themselves, as the minds and will of the producers, of course equipped with capital. The goods - the visible side of the market, objectified in the concrete physical forms of force and actions of entrepreneurial spirit. Here we have to revert to the dialectic of its request to seek a source of development in the contradictions and surprising transformations of opposites, spirit - in the material, the material - the spiritual. Fundamental and universal conclusion of the dialectic of concreteness of truth clarifies that what is true today will become a 


\begin{tabular}{|c|c|c|c|c|c|c|}
\hline \multirow{4}{*}{ Impact Factor: } & ISRA (India) & $=3.117$ & SIS (USA) & $=0.912$ & ICV (Poland) & $=6.630$ \\
\hline & ISI (Dubai, UAI & $=0.829$ & РИНЦ (Russia & $=0.156$ & PIF (India) & $=1.940$ \\
\hline & GIF (Australia) & $=0.564$ & ESJI (KZ) & $=8.716$ & IBI (India) & $=4.260$ \\
\hline & JIF & $=1.500$ & SJIF (Morocce & $=5.667$ & OAJI (USA) & $=0.350$ \\
\hline
\end{tabular}

delusion then. When? Naturally the question arises. The answer must be sought in the movement trends. Start as always with a comprehensive study of all of that. For us - a commodity, it required and optional (superstructure) signs.

Commodity production is due to the market. Once formed the market due to excess product and manifested in the form fair. Now the product is manufactured under the requirements of the market. The market, in turn, accumulates in real terms spending needs. Randomly appear on the market antique products or something very unusual new. In theory, taking into account the reasonableness of human activity, its rationality, mutual interest of the manufacturer, seller and the buyer can avoid the conclusion that all products will find their consumers. If the market will collect unsold goods, it will lose its function and will die as a market - place of purchase and sale. Almost as it sometimes happens. Once the market is not something abstract that exists outside of time. It is particularly time-shape reality.

Market - the most important link in ensuring the timely reproduction of goods. Market shares are not born out of fantasy. Sellers agree to bear certain costs, sequestered in their expectations just because of the need to do all the time. Otherwise, the loss will increase, the financial costs will join status. The risk would be the authority of the market participants themselves. In the context of these considerations matures the idea that the primary function of the market does not make any purchase, and get buy as soon as possible. Civilized organized market is designed to not only sell the goods in a timely manner, but also to be a factor in accelerating the development of the production of goods. How exactly this can be done?

Market The paradox is that the future is rosy market, all market problems are always modern, contemporary, they remain as the authorization of some and slew others. Where such confidence? From the analysis of objectively real reason market history. Basic market commodity the one that provides the necessary natural human needs. Out of the market to meet, without which it is impossible to public and individual reproduction impossible. Market - socially necessary condition of human life and its progress. The market should not only be imputed to him historically be a factor in the development of society. Accordingly, the destination market is supposed to be as a developing reality, and society to take care of development of the market. Do not give freedom "as able to swallow" (Boris Yeltsin)

Let's go back to the specific structure of the commodity market and will continue its analysis, starting from the original idea of "basic product". Satisfaction with the help of basic human needs requires decryption involving philosophical achievements. Can be done in a different way, simply, just simplification will lead to the prevention of "common sense", "simplicity worse than stealing." In the economic analysis of hazardous anything underestimated or overestimated. human reality is dualistic, incorporates biological and social. As a first approximation to share biological and social in man is simple.

Biological - meeting the nutritional needs of the body, keeping water and salt balance and metabolism is normal gas exchange, temperature conditions vital defense, reproduction progeny movement in space by means of self-movement.

Social - to meet the terms of employment, the development of thinking, consciousness, language, cultural progress.

Biological and social are combined based on the need for communication and implemented in dialogue through the activities. Social and interpersonal communication also requires its market expression. Biological and social aspects of human reality are manifold. They are not given once and for all, to grow, there are synthetic forms of manifestation. So the market prospects of natural essential goods and services provided, as well as market competition, following in the footsteps of its function to promote the mass availability of buyers to the products offered.

Development of the market is in concert with the development of man, his personal expression, new trends of social movements. The traditional market sectors XX century has added sports, scientific work, space, cinema, international tourism. Terror transformed into terrorism is largely due to the penetration of the market. Market terrorists actively use the services of the United States, the regional states to strengthen their political position. Especially when such actions have the desired effect on the conventional market and stock trading, for example in hydrocarbons.

Development of the market goes in the direction of increasing its autonomy. This vector are paying special attention to the representatives of finance capital, perfectly conscious that the market presents ideal conditions for speculative shares. Finally, the market in the XX century has become a favorite subject of economic science, tending to prove that the market forces are focused economy of motion. The market has become a symbol of the new economy, its leaders do not mind to give this symbol of the scale of socio-historical significance. The desire to imagine modern society as the "consumer society", "postindustrial society" must be understood in this way.

The market is not only a place where speculation has acquired massive size of the laws of phenomena, he eventually became the subject of speculation. Market speculation, and speculation on the market phenomenon - an objective reality, necessarily gives rise to market it, so to speak, the reverse side, the development costs.

However it was not significant for the history of the market of course - the required goods, ensure the 


\begin{tabular}{|c|c|c|c|c|c|c|}
\hline \multirow{4}{*}{ Impact Factor: } & ISRA (India) & $=3.117$ & SIS (USA) & $=0.912$ & ICV (Poland) & $=6.630$ \\
\hline & ISI (Dubai, UAI & $=0.829$ & РИНЦ (Russia & $=0.156$ & PIF (India) & $=1.940$ \\
\hline & GIF (Australia) & $=0.564$ & ESJI (KZ) & $=8.716$ & IBI (India) & $=4.260$ \\
\hline & JIF & $=1.500$ & SJIF (Morocco & $=5.667$ & OAJI (USA) & $=0.350$ \\
\hline
\end{tabular}

stability of the market movement in the near future, do not overestimate the significance of their natural necessity. Natural necessity product line indicates the nature, describes the essence of the subject. But the nature and essence of the goods does not act directly, they are mediated phenomenon that transformed the production form of the existence of material.

Low temperatures, high humidity, the need to guard against injury, meet the workplace and the specific duty would lead a person to the store and make it a potential buyer of the goods, which he lacks, but will make a purchase in one case, if nothing else never will .

This situation is not exactly fantastic, but looks somewhat implausible for modern Russia. Choosing our buyer is, as for the price, and on appeal. 9 out of 10 selected especially for the price, based on the contents of the purse, then focusing on the aesthetic satisfaction of claims.

Sellers can not panic, no crisis will deprive the market of customers. Their problem: it is the consumer who will buy it. He buys what he will see a combination of the need to purchase goods, free financial tools, more precisely, the prices on the price tags, and the appearance of the goods, including the art of service here. buying formula is simple - "needs, plus offers a charming urgency." The specific content of the terms must be filled specialists, drawing on the experience of market relations. From myself recall that the demand in the ordinary, non-exclusive, copyright market, is of two kinds: natural and artificial, provoked by promises of manufacturers and advertising process.

Domestic consumer got to the effect of "pop culture", "mass media" has lost the independence of taste, along with the ability to reflect. National coloring is largely lost, thriving cult of global, market is swamped with foreign consumer goods and counterfeit goods to which it is impossible to make a qualitative assessment.

The market develops specific cultural pattern, difficult to understand. State culture buyer is seriously interested. Previous experience of cultural education and upbringing expelled. "A holy place is never empty," and instead of the state came from the organizations of civil society, who have no formal authority or effective mechanisms nor the requisite financial resources. Scientists, economists convince entrepreneurs that need to cut everything not included directly in production, reducing costs, increasing profitability. By doing so, businesses are driving themselves into the trap of spontaneity and the vagaries of market forces by refusing to demand controls.

"Zealous housekeeper" that comes to replace the current irrational dispensation mass productionoriented absolutization of freedom of choice of goods by the consumer when the range required to satisfy the request for the here and now, otherwise the seller will lose customers and call into question the continuation of the business, "tied" to the knowledge of the specific needs buyer. Of course, such knowledge is specific, it is estimated, relative, conditional, more like the knowledge of a guess, but still knowledge as opposed to abstract the type of installation: the buyer item came and he should buy it, we are obliged to help him. How exactly? We do not know why his desire to initiate range. Certain logic and ethics in such reflections are present. Restrains the support price of this logic - high level of costs and the burden on the natural environment. They do not write off, are distributed to consumers by increasing the purchase price.

"The attractiveness of the product" can become a magnet, triggering the buyer's interest. No wonder VI Dahl interpreted "appeal" as an "appeal", "magnetism". The economic system is formed by the relations of production, radical transformation of the existing system of economy so it will not happen restructuring, reboot, not changing the system, and the order of operation of the system, vector evolution of economic policy. The economic system will take place optimization by rationalizing costs, minimize costs range.

Do consumers benefit? Apparently, yes, on the condition that the producers and sellers are not stingy with the research of consumer demand. There is already a simple investigation do not require in-depth analysis and aggregation of different approaches economic (marketing), sociological, cultural, ergonomic, San hygienic, emphasizing research on regional, national characteristics. This opens the prospect of real participation in the process of students of different levels, accelerating their qualification formation.

Going from good to better in any field of activity is associated with an increase in the cost of implementation, including financial risks. In our view, the analyzed transition to a new economic policy should meet the expectations imposed - lead to a reduction in costs, losses, environmental load, but the outcome will be largely determined he building science, technology and education and outreach policy. Good intentions often because, poor management completed the worst results.

Bad experience in the past is described even in the sacred books. The modification of the mass production economy in lean production involves the mobilization of scientific and technical initiatives, the maximum connection cultural assets and the implementation of the Soviet experience of educational work among the immediate needs of the final product. It is illogical to improve the principles and forms of organization of production, designed for mass consumption, without adequate training consumers. The adjective "mass", regardless of the desires, evidenced by the inclusion of activities in the political process, which requires the participation and political scale. The change of course within the 


\begin{tabular}{|c|c|c|c|c|c|c|}
\hline \multirow{4}{*}{ Impact Factor: } & ISRA (India) & $=3.117$ & SIS (USA) & $=0.912$ & ICV (Poland) & $=6.630$ \\
\hline & ISI (Dubai, UAI & $=0.829$ & РИНЦ (Russia & $=0.156$ & PIF (India) & $=1.940$ \\
\hline & GIF (Australia) & $=0.564$ & ESJI (KZ) & $=8.716$ & IBI (India) & $=4.260$ \\
\hline & JIF & $=1.500$ & SJIF (Morocco & $=5.667$ & OAJI (USA) & $=0.350$ \\
\hline
\end{tabular}

economic system is a political process with the characteristics, that it begins in the economy.

It came again time to temporarily disconnect from the production of goods and, following the example of Marx's focus on modern economic cell of the body - the product, but, in contrast to the "Capital" of the author to place the goods are not in production, and try to fit it into a subsystem of market relations. Capital without treatment is not capital. Capital - is a process. The process of reproduction of capital - a characteristic way of its existence. The market provides a reproduction of capital, creating conditions for the realization of marketable products. For the production of the initial capital required in the financial form for the realization of how reproduction of the conditions required demand for the product, which should provide the market - a condition of connecting producers and consumers. All, as we see, rests not in the characteristics of the product, and market organization. Of course, and properties of the goods are important. The doctor is able to revive the dying, but to revitalize the body is not able. The same can be said about the market.

As for the cultural organization of the market, its core is rational to do the work with the buyer and the manufacturer, the real object (the object) relations, which is a commodity, as a set of properties that can satisfy all market participants. Goods move from one property to another property only when there is a consensus. And aims to provide consensus market. Consensus - a measure of market culture.

When the market will move from the idea of consensus in the understanding of consensus, the market will gain the status of "cultural organization". You can speed up this process? Absolutely. It is necessary to organize the work on both fronts. Both the buyer and the seller must be prepared to meet the cultural market. Performing the actual market of the mission depends on the quality of scientific information and its equipment.

The social function of the market - to meet the socio-cultural and natural essential needs of the mass market, thereby contributing to national development and political progress. Economic commodity market task - to engage in the production of the financial reserves of the country's population, and they have a lot of really comparable to the annual budget of Russia.

Manage the market possible. Japan and China are economically different, however, in spite of this, successfully managing and production and the market. market management is different from the production management. The market is more difficult arranged in different directions, and responds to the desire to restore order. Orders, too heterogeneous. In the theater of the same order, at the races - the other, in the barracks - the third. Manage the market is possible (and desirable) economically.
The final stage of market relations - Product realization, hence to control the market follows through the conditions of sale of goods, creating a favorable environment of demand for the product. Such control is effective with respect to the consumer and the manufacturer. Construction market on the principle of "here and now the buyer must meet your request," saves time and possibly small amount of funding the consumer, but it is unnatural, because wasteful for society and nature. This "foppery" due to political short-sightedness.

Do not give up on it, the company put in a position of responsibility following generations. In question will be the future of the country and the people.

Transition to production-oriented market to a structure particularized consumption can be seen as a way to resolve the growing contradiction between the growing needs of the socio-cultural and natural sources. And in this sense there are enough grounds to speak about the objective laws of reproduction. the concentration of the center of activity shifted to the territory of the market, updated its scientific potential. Question №1 lean production: whether the market is ready for an increase in appropriations for the study of the structure of mass needs of the buyer? Specific examples of easy to find. Google at the end of June 2017 conducted a survey of the eating habits of Russians with a view to make a rating of 20 basic products and the same number of dishes. Russian consumer taste has encouraged marketers and horrified nutritionists. However, experts believe that two or three years, changes will not happen. Production, ensuring food market, has received the necessary information for consideration of investment in production lines. Now it is important to avoid excessive adjustment to agree on quotas within the respective unions, associations and other associations of producers.

We study well-known company interested in the context of the overall objectives of the plan, as it highlighted a few specific reasons for reflection. The first and probably the most important leads to the conclusion that economic theorists were late, and instead of the forecast again recorded a fact existing reality. Market, providing mass buyer need not have been, and it is unclear when it will be fit models marketers. He himself forms, adapting to the realities of production.

Domestic buyers in the first place put the egg in the middle sent pork and milk even further. Production of chicken meat and eggs have developed back in the 1970-80s, lost in the 1990s to save American farmers, later returned to his own farm, quickly restored in the right amounts. Market reliably provided these products in stock. Prices drop, manufacturer, their sellers are not overly inflate - no deficit, a network of stores manufacturers. The diverse range of products, timely its completion, quality, affordability of 


\begin{tabular}{|c|c|c|c|c|c|c|}
\hline \multirow{4}{*}{ Impact Factor: } & ISRA (India) & $=3.117$ & SIS (USA) & $=0.912$ & ICV (Poland) & $=6.630$ \\
\hline & ISI (Dubai, UAI & $=0.829$ & РИНЦ (Russia & $=0.156$ & PIF (India) & $=1.940$ \\
\hline & GIF (Australia) & $=0.564$ & ESJI (KZ) & $=8.716$ & IBI (India) & $=4.260$ \\
\hline & JIF & $=1.500$ & SJIF (Morocco & $=5.667$ & OAJI (USA) & $=0.350$ \\
\hline
\end{tabular}

products form the interest of the buyer them. Pork production also began to increase even in the prereform period, the peculiarity of growing swine herds can solve problems relatively quickly.

The hardest thing with milk. Market liberalism hardest hit by the weakest link of agriculture - dairy herd. It is up to the nineties was the mass in a state of neglect. Collective abolished, farming, designed to raise the production did not take place as intended. Cattle biology is such that the desired volume of herd animals with satisfactory performance should wait at least 10 years. Investing requires huge! West is not interested in us as a competitor. All of the above - it is a condition of instability and shortages. Market oriented at a deficit, and brought in cooperation with dairies its price order. Milk, affordable and high quality in the difficult Soviet era, and was of poor quality and inaccessible to the ordinary mass buyer. Particularly milk products. Consumer market weaned from milk. The question arises. Why? The market should be interested in the buyer. True, but in the production and intelligent people are working in the market. They understand that a herd of cattle will be a long time to form. Indefinite period of time produce a result is enough to take the greatest margin, and not necessarily rely on the mass consumer.

Second, the natural and socio-cultural needs of spontaneously formed only in the most general, abstract form. Narrow they in actual national reproduction, on the results of economic policy. The state is able to influence this process through the control of production and consumption, of course, in accordance with the laws of economics.

With that said, you can try to formulate a definition of what such an arrangement. It must be borne in mind that there are several different views of what such an arrangement, and a clear and absolutely clear definition of the properties of the individual can not be given.

In general, the location can be defined as an a priori relation to the person, group of people, events, organizations, processes and things that determines a positive or negative reaction to them.

Location has three components. Firstly, it is the part that reflects a person's feelings about the project: whether he likes it or not. This part is called the acting part of the arrangement. Secondly, it is the knowledge about the object, which has a man. Thirdly, it is the intention about how to behave in relation to the object. Uniting together the three parts forming person location to the object, wherein finding the dynamic linking connection between knowledge of the object person, his feelings about the object and its intentions with respect to that object.

Human location in relation to the phenomena, processes, and people formed on the basis of training, based on life experience. Usually, a positive or negative relation to the object is formed as a result of whether the object is caused satisfied or not. In this arrangement the formation occurs both by evaluating the experiment (satisfaction - dissatisfaction) interact directly with the object and by correlating the object with other objects, against which formed a certain location.

The connection between the behavior and the location is ambiguous. The fact that a person that does not love, does not follow a hundred percent fact that he did not fully accept. But, nevertheless, in most cases, a person's behavior is influenced by location. In this connection, an important task of management is to develop and change, if necessary, the location of the organization.

Essential for good governance and the establishment of good relations in the organization are the three. location type:

- - job satisfaction;

- - passion for work;

- - commitment to the organization.

The extent to which workers have developed these arrangements, essentially determines the results of their work, absenteeism, employee turnover, etc.

Job satisfaction has a very strong influence on human feelings towards the work, so it can be attributed more to the impact of components. Job satisfaction depends on many factors, both internal and external to the person.

However, when a large variety of different factors, and orientation of their effects on human allocated eight working characteristics, from which job satisfaction depends quite stable:

- - the nature and content of the work;

- - the volume of work performed;

- - state of the working space and its surroundings (noise, lighting, comfort, air temperature, etc.)

- - co-workers;

- - leadership (heads, style of leadership, participation in management);

- - payment for work (all forms of payment);

- - promotion opportunities at work;

- - routine, rules of conduct, etc.

These characteristics are rather general in nature. For each real work, they can be specified or supplemented depending on the nature of the organization, its characteristics, etc. Practice also shows that the priority of these characteristics can also vary considerably among individual members within the organization and among different organizations. And finally, in relation to the needs of individual characteristics stable operation impact on job satisfaction over time can begin to provide new or previously irrelevant characteristics of the work. Therefore, to successfully manage and create a positive location for the organization should regularly carry out a study to determine the degree of employee satisfaction with the organization of its work. 


\begin{tabular}{|c|c|c|c|c|c|c|}
\hline \multirow{4}{*}{ Impact Factor: } & ISRA (India) & $=3.117$ & SIS (USA) & $=0.912$ & ICV (Poland) & $=6.630$ \\
\hline & ISI (Dubai, UAI & $=0.829$ & РИНЦ (Russia & $=0.156$ & PIF (India) & $=1.940$ \\
\hline & GIF (Australia) & $=0.564$ & ESJI (KZ) & $=8.716$ & IBI (India) & $=4.260$ \\
\hline & JIF & $=1.500$ & SJIF (Morocco & $=5.667$ & OAJI (USA) & $=0.350$ \\
\hline
\end{tabular}

Stably great effect on job satisfaction increase has nature and content of the work. Therefore, we consider in more detail the influence of the individual components of this factor.

Long time of standardization and specialization of work were considered and in practice is very strong sources of increasing productivity at work. The higher the standardization and specialization, the higher the performance of the work. However, the relationship between satisfaction with it, and its standardization and specialization is of a different character. If the work is not completely standardized, the job satisfaction is low. With increasing specialization and standardization it begins to grow, but to a certain point, after which it begins to decline rapidly. With the full standardization of satisfaction drops to as low a level as if the work was not completely standardized. Therefore, management should think about how to reduce the negative impact on satisfaction, performance, generated by excessive specialization and standardization. The two most common ways of implementation are rotated (worker movement from one workstation to another) and the expansion work responsibilities to the employee by raising additional tasks.

Clarity of job content, role clarity (especially with regard to the content of other roles), there is a clear feedback that informs the individual of the results of its work in certain circumstances, may lead to increased job satisfaction. To the greatest extent it manifests when there is a clear and formal delimitation of roles in the organization.

The presence of elements of the call at work, such as creativity, ability to use their original individual or unique skills, the complexity of tasks, etc., leads to higher job satisfaction. At the same time, a boring job, as studies show that usually reduces the satisfaction with it.

Enthusiasm for work is one of the best locations that determine how a person comes to his work, to his participation in the process of working together. Develops two types of interest in work. One type - is the love of work in general, with little regard to what exactly to do. People with this type of dedication is called workaholics, ie people working, loving work and seeking work. This type of arrangement is formed by raising a child, though in more later in life there are cases of this location. Another type - a love for the particular work that a person does in an organization. Both of these types do not necessarily go together, but between them and there is interdependence.

Passion for work is characterized by three aspects. Firstly, it is the extent to which the work takes a significant, central place in human life (the importance of). Secondly, as far as the work itself attracts people (labor). And, thirdly, how a person identifies their personnel with the work carried out by them (working attributiveness). Analysis of these three areas to determine the extent of the human passion for his work. It is necessary to take into account that each of these aspects of interest in work is relatively independent and, depending on the personality characteristics of the person can be in varying degrees affect his enthusiasm for the work.

\section{Commitment to the organization}

It is positioned substantially wider than the passion for work, or job satisfaction. In modern conditions, when more and more organizations are trying to look at the person, not as an employee performing a specific job, but as a member of the organization, striving together with the rest of its members lead the organization to achieve the goals, the importance of this location becomes extremely high. Commitment to the organization is made up of the following components. Firstly, the organization shares the member makes their own goals of the organization and its values. Second, the organization strives to remain a member of the organization and maintains this aspiration even when it may be disadvantageous for him. Third, member of the organization is ready not only to try to organize, but if it is necessary,

Commitment to the organization - the personal characteristics of each individual. However, this does not mean that management can not develop or strengthen this location. There are a number of techniques to facilitate this. And the most successful modern is very much a control system based on the fact that they are developing the employees a strong commitment to the organization and achieve thanks to a very great success.

Values as well as the location, have a strong influence on the preferences of the person, on its decisions and behavior in the team. However, between the values and the location is a huge difference. If the latter determine the relationship of man to the object on the principle of "like - not like", "like - not like" and always refer to any particular object, then set the value of human preference for the principle of "reasonable - is unacceptable", "good - bad "' useful harmful ", etc. In this case, values are rather abstract and general in nature, live an "independent" life, regardless of the particular person, formulated in the form of the commandments, statements, wisdom, common standards and can be separated by large groups of people. Therefore, if the location is always highly personalized, the bearers of values are a group of people for example.

Values can be defined as a set of standards and criteria that a person must be in their lives. This is manifested in the fact that by appropriate assessment taking place around the phenomena, processes and people person decides and carries out its activities.

Values are at the core of human personality. They are fairly stable over time, and not so much. Typically, values are considered as a normative moral 


\begin{tabular}{|c|c|c|c|c|c|c|}
\hline \multirow{4}{*}{ Impact Factor: } & ISRA (India) & $=3.117$ & SIS (USA) & $=0.912$ & ICV (Poland) & $=6.630$ \\
\hline & ISI (Dubai, UAI & $=0.829$ & РИНЦ (Russia & $=0.156$ & PIF (India) & $=1.940$ \\
\hline & GIF (Australia) & $=0.564$ & ESJI (KZ) & $=8.716$ & IBI (India) & $=4.260$ \\
\hline & JIF & $=1.500$ & SJIF (Morocco & $=5.667$ & OAJI (USA) & $=0.350$ \\
\hline
\end{tabular}

base and foundation of human behavior. Values are of two types:

- values related to the purpose of life, the desired results, the outcome of the action, etc.;

- the value relating to the means used by man to achieve the objectives.

The first type includes values, such as values relating to the comforts of life, beauty, peace, equality, freedom, justice, satisfaction, self-esteem, social acceptance, friendship, etc.

The second type of values are the values on ambition, openness, honesty, kindness, intelligence, commitment, responsibility, self-control, etc.

A set of values, which should be a man of his value system, in which the surrounding judged that he is as a person.

Valuable human system is formed mainly in the course of his education. Many people value gets under the influence of parents and other people close to him. Strongly influenced by the education system, religion, literature, cinema, etc.

Value system is subject to development and change, even into adulthood. Important role in this played by the organizational environment. For organizations that are seriously thinking about the harmony of human values and organization values, on the combination of these two systems of values given serious consideration. In particular, much work is done by clearly articulating, explaining and bringing to all members of the organization of the system of values, which should be an organization. Considerable attention is also paid to and clarification of what value orientations are members of the organization.

beliefs. Very often people make decisions based on the phenomena of estimates or opinions about the quality of these phenomena. If these estimates are quite stable and do not require the relevant evidence, then they turn into beliefs. In general, the beliefs can be defined as a stable representation of the phenomenon, process or person that people use in their perception. Beliefs may change over time. However, at a time when a person has some specific beliefs about the object, it usually takes and. evaluates object in accordance with these beliefs. With regard to the same object can have many different beliefs, because beliefs are usually refer to individual characteristics of the object. For example, about one and the same person can have the following beliefs: 1 ) a reliable person; 2) good specialist;

Beliefs are developed on the basis of individual experience, as well as on the basis of information coming from external sources. Very often beliefs are characterized by a generalization of a single experience. They occur frequently in humans as a result of other people's ability to convince of the rightness of his opinions, his beliefs. Therefore, even though a person takes their beliefs for the truth, they do not always fully correspond to reality.

Beliefs can be divided into two large groups.
The first group consists of describing the absolute and relative performance object beliefs that have no evaluative. For example, the car "Zhiguli" is a comfortable car or a car "Zhiguli" consumes gasoline is less than the car "Volga". The second group includes those beliefs that are estimates. For example, the car "Zhiguli" is better than the car "Volga". Beliefs have a significant impact on the location, especially to the one of its components, which is associated with knowledge about the object.

Particularly strong influence the second group beliefs. Therefore, given that beliefs do not always correspond to reality, to not form the wrong location in relation to the object, which may adversely affect the interaction between man and the environment, must be critical and skeptical approach to their beliefs and cautiously enough to perceive the beliefs of others.

The principles in the lives of many people play a very important role, as they systematically regulate their behavior. Principles are embodied in stable behavioral norms, constraints, taboos, sustainable forms of reaction to the phenomena, processes and people. Principles are formed on the basis of a system of values, are the stable form of manifestation of the values and beliefs of the embodiment in the form of certain standards of behavior, people are not necessarily aware of what values and beliefs are embodied in the individual principles. Often principles are accepted by people as beliefs, and they follow them in their activities without wondering about the justification of these principles and why they follow them. Principles can be produced by people themselves.

Human impact on the individual company management for its effectiveness.

All people in something similar to each other. And it allows us to speak of man in general, talk about its features, especially the behavior, etc. However, no single man is an impersonal "man in general". Each brings something that makes it unique, exclusive, ie, person has a personality. Such a person enters the organization, such a person performs a specific job and plays a role in the organization, it is the kind of person you want to manage, helping him to discover and exploit their potential in solving the tasks of the organization, creating the conditions necessary for its success, the interaction with the organizational environment and solve their own problems in life.

Individuality man consists of three began. First, each person in something similar to everyone else. Secondly, every person in something the same with some other individuals. And finally, thirdly, everyone in something does not look like anyone else. Depending on how the combination of these "principles" of reinforced concrete individuality of each person. At the same time, no matter how built this combination, we must always remember that 


\begin{tabular}{|c|c|c|c|c|c|c|}
\hline \multirow{4}{*}{ Impact Factor: } & ISRA (India) & $=3.117$ & SIS (USA) & $=0.912$ & ICV (Poland) & $=6.630$ \\
\hline & ISI (Dubai, UAI & $=0.829$ & РИНЦ (Russia & $=0.156$ & PIF (India) & $=1.940$ \\
\hline & GIF (Australia) & $=0.564$ & ESJI (KZ) & $=8.716$ & IBI (India) & $=4.260$ \\
\hline & JIF & $=1.500$ & SJIF (Morocco & $=5.667$ & OAJI (USA) & $=0.350$ \\
\hline
\end{tabular}

people are always at the same time has to do with the rest, and is not like the others.

Each person has a stable set of features and characteristics that determine his actions and behavior. These characteristics manifest themselves in a fairly long period of time, so you can feel secure and individuality.

A particular person is fixed on the environment of his personality as individuality has a certain stability, people know each other and keep a certain relation to each other. At the same time it should be noted that under the influence of experience, communicate with others, education and training there is a change of human individuality, sometimes very significant.

Individuality is influenced by three groups of factors. The first group consists of heredity and physiological characteristics of a person. Heredity preserves and transmits the external features of the person. But not only. Studies conducted with twins, suggest that genetics may carry and transfer of certain behavioral traits. Human Physiology suggests that a lot in common determines their behavior in humans. In particular, it is the same for all the general adaptation syndrome, reflecting the physiological response to the stimulation.

The second group of factors that shape human personality, constitute factors arising from man's environment. In general, the effect of these factors can be considered as an influence on the formation surrounding the individual. Firstly, a strong effect on the human individual has a culture in which it is formed. Man receives from society norms of behavior, learns under the influence of certain cultural values and beliefs. Second, the human personality is strongly determined by the family in which he grew up. In the family, children learn certain behavioral patterns, produced by their attitudes, attitude to work, the people, their responsibilities, etc. Third, it has a strong influence belonging to certain groups of organizations on human individuality, The man produced a definite identification that specifies a certain type of individual to him, to which he himself embodies and sustainable forms of behavior and, in particular, respond to the impact from the environment. Fourth, the formation of personality is influenced by life experience, individual circumstances, random events, etc. Sometimes it is this group of factors can lead to significant changes in human personality.

The third group of factors that influence the formation of individuality constitute features and characteristics of human nature, its individuality. That is, in this case the situation with the formation of personality as follows: personality affects their own formation and development. This is due to the fact that a person has an active role in their own development and is not exclusively a product of heredity and environment.
With all the depth of the human personality and its diversity, you can identify some areas of its characteristics, which can be described as personality.

There are people who prefer to keep their distance from others, and this has a significant impact on their behavior in the team. People with authoritarian character believe that there must be order and the difference in the status and position of people seeking to establish a hierarchy of relationships and the use of force in decision-making and management, readily recognize and appreciate the power of conservative values. Love and faith in people as an individual trait have a strong impact on human interaction with others. This is particularly evident in the willingness to participate in group activities, to promote the development of contacts, interaction and mutual support.

Sensitivity to other people is manifested in the ability of people to empathize with others, take to their heart problems, the ability to put yourself in the place of another, etc. People with these personality traits are well accepted in the community and seek to communicate with people.

Stability in behaviors man plays a big role in its relationship with the environment. If a person is stable, responsible and generally predictable, then environment perceive it positively. If, however, he is constantly unbalanced, capricious and unpredictable steps tend to do, the team reacts negatively to such a person.

Self-esteem ,those. the way people look at their behavior, capabilities, capabilities, appearance and the like, has a profound effect on human behavior. People with higher self-esteem usually achieve more in life, as they set themselves higher goals and strive to solve more complex problems. At the same time, people with low self-esteem often put themselves in a dependent position and easily submit to people with higher self-esteem.

The perception of riskIt is an important behavioral characteristic, clearly reflecting the individuality of the person. People who are inclined to risk, less time is spent making decisions and are ready to make decisions with less information. In this case, the result of the decision is not necessarily worse than those who meticulously prepares the solution and collect all the necessary information.

Dogmatism is usually a trait of individuals with limited sight. Dogmatists see the environment as the concentration of risks, refer to the authorities as absolutes and perceive people according to how they relate to the dogmas and absolute authority. Usually dogmatists are people with authoritarian traits. The dogmatists do not tend to look for a large amount of information, quick enough in the decision, but at the same time demonstrate a very high level of confidence in the accuracy and correctness of decisions. It is noted that the dogma prefer to work in a wellstructured groups, regardless of what position they 


\begin{tabular}{|c|c|c|c|c|c|c|}
\hline \multirow{4}{*}{ Impact Factor: } & ISRA (India) & $=3.117$ & SIS (USA) & $=0.912$ & ICV (Poland) & $=6.630$ \\
\hline & ISI (Dubai, UAI & $=0.829$ & РИНЦ (Russia & $=0.156$ & PIF (India) & $=1.940$ \\
\hline & GIF (Australia) & $=0.564$ & ESJI (KZ) & $=8.716$ & IBI (India) & $=4.260$ \\
\hline & JIF & $=1.500$ & SJIF (Morocce & $=5.667$ & OAJI (USA) & $=0.350$ \\
\hline
\end{tabular}

occupy in the group. It was also noted that the dogma poorly aware of how they spend their time during the work, and the fact that they are poorly cope with the administrative work.

The complexity of understanding phenomena as a characteristic of human individuality reflects its ability to decompose knowable phenomenon into parts and to integrate, synthesize general ideas or opinions about the conscious phenomenon. People with a high awareness of the complexity of showing great ability to process information, consider increasing the number of options and take a more comprehensive solutions than people with low awareness by the complex. It is noted that the leaders of the high complexity of understanding in situations with a wide variety of environments better able to cope with their responsibilities, that this type of managers is more prone to extensive contacts with people than the leaders of low-complexity awareness, as well as the fact that these leaders tend to use a variety of resources to solve problems.

The sphere of control It reflects the way an individual looks at the source of the factors determining its validity. If a person believes that his behavior depends upon himself, in this case characterized by the presence of the internal sphere of control (introverts) for him. If he believes that all depends on the case, external circumstances, actions of other people, it is considered that it has an outer sphere of control (extroverts). Introverts better control their actions are more focused on achieving results, more active, more satisfied with their jobs. They enjoy an informal management style, they like to influence others, but do not like to work on myself, like to hold managerial positions. Extroverts, on the contrary, prefer the formal structure prefer to work under the policy guidance. If they hold managerial positions,

There are a large number of tests and other tools to determine the characteristics of individuality. In modern management these issues, and this type of activity is given a lot of attention. And this is due primarily to the fact that the organization's success depends on how well it can use all the means at its disposal in the human potential.

The need to study the human personality is also caused by the fact that is usually done many wrong conclusions about people, about their characteristics, their personality. This is due to the fact that people in other knowledge based on stereotypes, prejudices, baseless generalization. Doing the wrong conclusions about the identity of the people, we are creating the basis for hazardous conflicts, scandals, gossip, difficulties in communication and interaction between people. These are all detrimental to individuals and the organization as a whole.

Fact need thorough and regular examination of individual characteristics of members of the organization is not in doubt. However, recognizing the importance and usefulness of this type of management, and it must be remembered that the individuality of human behavior depends not only on his personal traits, but also the context in which it takes action. Therefore, the study of man must always be carried out in conjunction with the study of the situation.

Finally, the study of human personality must take into account his age. A man walks into their lives different stages, which corresponds to a different state of his personality. Therefore, making conclusions about a person's character, his personality, it is necessary to proceed from the fact that his behavior is very much defined by what it is instar. Only the records of all of these factors together can give a clue to the human personality, and therefore, to the person managing.

Influence of individuality on its interaction with the enterprise team.

As mentioned above, the organization expects that people will perform in a certain way a role for which she receives it. The man is also looking at the organization as a place where he gets some work, executes it and receives appropriate remuneration from the organization. However, the interaction between man and the organization is not limited to the role interaction. It is much broader. The person doing the work surrounded by people in interaction with them. He not only played the role in the organization, but also a member of the group in which it operates. The group has a profound effect on human behavior. A person's behavior, his actions make a definite contribution to the life of the group.

There is no canonized definition of a small group, as it is quite flexible and are exposed to circumstances phenomenon. However, the widely adopted fairly common, well-established view on a small group (hereinafter always the term "group" will be used in this sense) as a relatively separate union of a small number of people (usually not more than ten twenty-five) are in a fairly stable cooperation and implementing joint actions for a sufficiently long period of time. Interaction of group members based on some common interest and may be associated with achieving a common goal. The group has a certain potential for the group or group capabilities that allow it to interact with the environment and adapt to changes in the environment. follows.

The characteristic features of the group are as

First of all, Group members identify themselves and their actions to the group as a whole and thus in external interactions act as if on behalf of the group. Man does not speak about himself, but about the group as a whole, using the pronoun we, we, our, us and the so-called

Secondly, the interaction between the group members is in the nature of direct contact, personal conversation, observation of the behavior of each other, etc. In the group of people to communicate 


\begin{tabular}{|c|c|c|c|c|c|c|}
\hline \multirow{4}{*}{ Impact Factor: } & ISRA (India) & $=3.117$ & SIS (USA) & $=0.912$ & ICV (Poland) & $=6.630$ \\
\hline & ISI (Dubai, UAI & $=0.829$ & РИНЦ (Russia & $=0.156$ & PIF (India) & $=1.940$ \\
\hline & GIF (Australia) & $=0.564$ & ESJI (KZ) & $=8.716$ & IBI (India) & $=4.260$ \\
\hline & JIF & $=1.500$ & SJIF (Morocco & $=5.667$ & OAJI (USA) & $=0.350$ \\
\hline
\end{tabular}

directly with each other, giving a formal interactions "human" form.

Thirdly In the group along with the formal distribution of roles, if any, necessarily develops informal roles, usually recognized as a group. Individual members of the group take on the role of generators of ideas, while others tend to coordinate the efforts of team members, and others concerned about the relationship between the group of maintaining a good climate in the team, the fourth track of the fact that there was an order to work, all carried out in time and brought to the end. There are people who perform the role of the Outliner, they set group goals, monitor the impact of the environment on the decisive group tasks.

These and other roles of group behavior people perform in accordance with their abilities and inner calling. Therefore, in a well-functioning groups are usually created opportunities for a person to behave in accordance with their abilities to group actions and organically inherent in it a particular role in the group.

There are two types of groups: formal and informal. Both of these types of groups are relevant to the organization and have a great influence on the members of the organization.

formal groups usually identified as the structural units of the organization. They have a formally designated leader, formally defined roles structure of posts and positions within the group, as well as formally assigned to them the functions and tasks. Formal groups can be formed to perform regular functions, such as accounting, and can be created for a specific target, such as the Commission on the development of a project.

informal groups are not orders leadership and formal regulations, and members of the organization in line so mutual sympathy, common interests, same hobbies, habits, etc. These groups exist in all organizations, although they are not represented in the schemes that reflect the structure of the organization, its structure. Informal groups usually have their own unwritten rules and norms of behavior, people are well aware of who is part of an informal group of them, and who is not, in the informal groups formed a certain distribution of roles and positions. Usually these groups have explicitly or implicitly defined leader. In many cases, informal groups can exert influence on its members, an equal or even greater! The formal structure.

Why am I having a group that causes people to form groups and to join them? These questions are very important for the understanding of human behavior in organizations. It is obvious that the group appear in the organization and functioning as a separate structural unit in connection with the fact that as a result of the division of labor are allocated separate specialized functions, requiring for their execution of a certain set of people with a qualification, having a certain profession and finished in a system of joint activities to perform some work. A similar situation is observed in the formation of groups to resolve targets.

But this is only one side of the appearance of groups in the organization. Usually it leads to the formation of formal groups. Another important reason for the formation of groups is a natural human desire to unite with other people, to the formation of resistant forms of interaction with people. Group gives a person a sense of security, from the group, he is waiting for support, assistance in solving their problems and warnings. In the group the person easier to achieve a "reward" in the form of recognition, praise or material reward, a person learns in a group, learning from the experience of other, better aware of their capabilities and potential. Group gives a person more confidence in external interactions, contributes to its Identity. *

* This term reflects human identity, his identification with certain stable phenomenon or condition.

Finally, the group provides a person the opportunity to pass the time in a pleasant environment for him, to avoid loneliness and state of helplessness, worthlessness. Every person aspires to being loved by someone, fit someone belong to someone, and the group can be a source of solutions to these human problems.

On the influence of the collective identity on the effectiveness of enterprise management

Regardless of the type of the group, in which organization is formed and functions, as well as someone who specifically included in the group may indicate some common elements and factors characterizing construction group, its structure and operation process of the group in its environment.

The life of the group, its functioning is influenced by three factors:

- characteristics of the group members;

- structural group characteristics;

- situational characteristics.

All of these factors are not only in the interaction, mutual influence, but also experience a strong feedback effect on the part of the functioning of the group as a result of vital activity of the group is changing characteristics of the person, changes the construction of the group and there are changes in its environment.

The characteristics of the group members Influencing its operation, are the personal characteristics of the person, as well as abilities, education and experience. Above we have discussed in detail the personal characteristics human, so we will not dwell on them in this review. As for the other characteristics, it is noted that a person's ability to perform the work have a great impact on the functioning of the group and to perform its role as a man. Also, a significant impact on the level of the group have rights education and life experience. 


\begin{tabular}{|c|c|c|c|c|c|c|}
\hline \multirow{4}{*}{ Impact Factor: } & ISRA (India) & $=3.117$ & SIS (USA) & $=0.912$ & ICV (Poland) & $=6.630$ \\
\hline & ISI (Dubai, UAE & $=0.829$ & РИНЦ (Russia) & $=0.156$ & PIF (India) & $=1.940$ \\
\hline & GIF (Australia) & $=0.564$ & ESJI (KZ) & $=8.716$ & IBI (India) & $=4.260$ \\
\hline & JIF & $=1.500$ & SJIF (Morocco) & $=5.667$ & OAJI (USA) & $=0.350$ \\
\hline
\end{tabular}
include:

The structural characteristics of the group

- communication in a group and rules of conduct (who is with whom and how to contact);

- the status and role (who occupies what position in the group and making);

- personal likes and dislikes among the members of the group (someone who likes whom and who does not like);

- power and conformism (any man has an impact and who is for whom to, someone who will listen and who obey).

The first two structural characteristics of the group are more to the organizational aspect of the analysis of its functioning, so they will not be discussed here. Next will be considered only structural issues of interpersonal interactions in the group.

sympathy; and antipathy between people It is mostly individual color and background. However, it became clear that the establishment of friendly relations between people have a significant impact several points.

First of all, very strongly influenced by personal characteristics interact. People love those who like the same phenomena, things, processes that are like them, ie people like those who like them, who are close to them in spirit, taste and preferences. Naturally, there are exceptions. However, studies show that people are attracted to those who have the same or close to them, race, nationality, education, a system of views on life, etc. Potentially, people with similar personal characteristics have a great chance to establish friendly relations than those with personal characteristics are significantly different.

Secondly On the development and establishment of friendly relations between the people, for the development of mutual affection is greatly influenced by the presence of proximity to the location of these people. The closer are located the jobs of group members, the greater the likelihood that they will establish friendly relations. The same applies to the proximity of their residences.

Thirdly, the establishment of friendly relations is in direct proportion to the frequency of meetings, as well as the expectation that the meeting will occur frequently in the future.

Fourth, the relationship between the group members, their mutual likes and dislikes, friendly atmosphere in the group depend on how successful the operation of groups. In general, success leads to people developing a positive attitude towards each other to a greater extent than the unsuccessful operation of the group.

Fifth And the development of friendly relations between the members of the group contributes to the presence of a single goal, which are subject to the actions of all members of the group. It is noted that, if the members of the group are separated solution of individual tasks, mutual sympathy and friendliness fold less than if they were working on a solution common to all tasks.

At sixth, The positive orientation with respect to each other occurs when practiced in a group wide participation of all group members in the decision. The opportunity to influence the general group processes stimulates the development of party members' positive perception of the group.

Without a doubt, the existence of sympathy between people, the presence of friendly relations between the members of the group has a huge impact on the mood of the people, their satisfaction with their work, their membership in the group. However, one can definitely say that the friendly relations between the members of the group have only a positive impact on the results of their work and the results of the functioning of the group as a whole. If people who have friendly relations with each other, are highly motivated to work in a group, the presence of mutual sympathy and friendship contributes to a significant improvement of the results of their work and thus has a positive effect on the functioning of the group as a whole. If these people are poorly motivated to work, the result is quite the opposite. They will spend much time in useless for conversation, smoke breaks, teas, etc., are constantly distracted from work and greatly reducing the effectiveness of its work. However, they can distract from the work of others, creating a group atmosphere of idleness and relaxation.

Mutual support on the basis of sympathy and friendship, promoting group cohesion can generate a synergistic effect of significantly enhancing the effectiveness of the group. Modern management practices are becoming more and more confirms the obvious advantages in group forms of work organization to the individual. A clear illustration of this is in particular the so-called Japanese style control.

However, with distinct advantages over other forms of work organization, group form can carry a number of negative aspects for the organization. One such negative phenomena is cliquism, folding preferably in close relationship between members of the group, with the proviso that in general delivered incorrect control group and its functioning incorrectly arranged in the organization.

Factionalism manifested in the fact that the group is closed in itself, weak and incorrectly responds to external signals, rejects the criticism, etc. All this is reflected in the fact that, firstly, the group develops a tendency moralization process, of course, accompanied with the presentation of themselves and their action at best morally light. Secondly, the group begins to feel invulnerable and invincible, even in conflict collisions. Third, the troupe consists of conformism atmosphere, the desire to get everyone to agree with the common opinion, the unwillingness to listen to and discuss different opinions and points of view, etc. Fourthly, the group develops consensus. 


\begin{tabular}{|c|c|c|c|c|c|c|}
\hline \multirow{4}{*}{ Impact Factor: } & ISRA (India) & $=3.117$ & SIS (USA) & $=0.912$ & ICV (Poland) & $=6.630$ \\
\hline & ISI (Dubai, UAI & $=0.829$ & РИНЦ (Russia & $=0.156$ & PIF (India) & $=1.940$ \\
\hline & GIF (Australia) & $=0.564$ & ESJI (KZ) & $=8.716$ & IBI (India) & $=4.260$ \\
\hline & JIF & $=1.500$ & SJIF (Morocco & $=5.667$ & OAJI (USA) & $=0.350$ \\
\hline
\end{tabular}

People are starting to think more and more like the rest. And even if they have other opinions, they do not speak, because they themselves doubt them, believing that the general opinion is true. Fifth,

The power and conformism in the relationship between members of the group appear in the form of so-called social influence on the person. The group is putting pressure on the person requiring it to follow group norms, rules requiring submission to the interests of the group. A person can resist this pressure, and may assign a group - comply, i.e. conformist act.

One can not say that one type of human relations with a group of the faithful, and the other not. Obviously, the conformism can lead to the fact that the person even realizing the infidelity of their actions, implementing them because the group does so. Conformism can turn a man into a dumb appendage group. History knows a lot of negative examples of how the "herd instinct", or, to put it another way, unconditional conformity underlying the terrible crimes against individuals and humanity as a whole. She knows examples of how the group is completely erased the human personality, turning him into a cog in the mechanism of the group. At the same time, it is obvious that without the conformism can not be created close-knit group, can not be established balance in the relationship between a person and a group.

Since conformism in human relationship with the group on the one hand, acts as a condition of integration of the individual into the group, and on the other - could give rise to negative consequences for the environment and for the group as a whole and of the individual in particular, the important thing is figuring out which factors and to what extent the demand from members of the group to make concessions to public influence.

The nature of problems to be solved It has a significant impact on the degree of conformity in human behavior. If the objectives are not clearly definable, if they do not have a clear answer, then they make the person performing them, more than to be influenced by the group. The degree of conformity also depends on whether the member of the group gave a public commitment regarding the problem to be solved or not, but also because, at what stage of the decision he announced his commitment. Public and early application make a person more susceptible to social influence. Conformism in human behavior develops payment by results of group work.

Feature group also it has a great influence on the development of the person of conformity in relation to the group's requirements. Unanimity in group behavior enhances the degree of influence on the human group. Man is easier to argue or disagree, if someone else in the group has an opinion different from the group. On the conformity of human behavior in the group affects the number of groups. If a group of five people, the consensus begins to exert a strong influence on the individual. The further growth of the group has little effect on increasing the influence of the group on the person. The degree of conformity to the group of human behavior also depends on the proximity of leadership in group activities and frequency of contacts with the leadership. If the chief is often present and involved in decision-making member of a group, it leads to an increase in the behavior of the slave conformism.

Desire to obey the influence from the group, directly depends on personal relations between the members of the group, their likes and dislikes, friendship, etc. The better the personal relationships between members of the group, the higher the degree of conformism in their behavior in the group and the higher the possibility of public influence on the members of the group.

Situational characteristics of the group little influenced by the behavior of group members and the group as a whole. These characteristics are related to the size of the group, its spatial arrangement, problems solved group and compensation system used in a group.

In small-sized groups, there is more difficulties reaching an agreement, and much time is spent on finding relationships and points of view. In larger groups, there are difficulties in finding information, since the members of the group are usually more reserved and concentrated. It was also noted that in groups with an even number of members, although there is more tension with the decision than in the groups with an odd number of members, and less than disagreement and antagonism between the group members.

Group size also it has an effect on job satisfaction. Some studies show that people are more satisfied, if they are working in a medium-sized group (5-6 people). Small groups generate a lot of tension in the relations between its members, and in the large is not given enough time for each group member.

The spatial arrangement of the members groups has a marked effect on their behavior. It's one thing when a person has a permanent location, another when he is looking for every time imagine this place. People at work can look at each other, and can be arranged back to back. And it will also have an impact on their work and on their behavior in the group.

There are three important characteristics of the spatial arrangement of the individual, on which depend the relationship between man and the group.

First of all Is a permanent or a certain place or territory. The man knows this is my table, this is my machine, it's my job. Lack of clarity on this issue raises many problems and conflicts in interpersonal relationships, as well as significantly reduces job satisfaction.

Secondly This private space, ie the space in which the body is just the person. The spatial 


\begin{tabular}{|c|c|c|c|c|c|c|}
\hline \multirow{4}{*}{ Impact Factor: } & ISRA (India) & $=3.117$ & SIS (USA) & $=0.912$ & ICV (Poland) & $=6.630$ \\
\hline & ISI (Dubai, UAI & $=0.829$ & РИНЦ (Russia & $=0.156$ & PIF (India) & $=1.940$ \\
\hline & GIF (Australia) & $=0.564$ & ESJI (KZ) & $=8.716$ & IBI (India) & $=4.260$ \\
\hline & JIF & $=1.500$ & SJIF (Morocco & $=5.667$ & OAJI (USA) & $=0.350$ \\
\hline
\end{tabular}

proximity of the location of people can generate many problems, because people are not perceived proximity to them other people without regard to age, gender, etc.

Thirdly, This relative position of seats. It is noted that if the jobs are fenced off from each other, it contributes to the development of formal relations. Availability of jobs a team leader in a common space helps to activate and consolidate the group. If people have jobs at the head table, it is in the eyes of others in the group automatically puts him in the position of leader. Guide, knowing these and other members of the group location issues can make significant impact and improve the efficiency of the group only through proper placement of jobs.

The impact of problems solved by the group on the functioning of the group and the behavior and interaction of team members is obvious. However, it is very difficult to establish the relationship between the types of problems and their impact on the life of the group. It is noted that the solution of formal problems, such as mathematics, to a lesser extent contribute to the development of relations between members of the group than the solution of problems in the humanities. It is known that the tasks and functions performed by a group, affect the style of leadership, as well as the style of communication between people. In the case of poorly structured or unstructured problems there more pressure on an individual and group interdependence action than in the case of a wellstructured problems.

You can point out a few characteristics of the problem, which is important to pay attention to in order to try to determine the solution of this problem will affect the group as a whole and the behavior of its members.

First of all, It is necessary to determine how much interaction will occur between members of the group in the process of solving the problem, and how often they communicate with each other.

Secondly, It is necessary to find out how the actions performed by individuals are interdependent and mutually influence.

Thirdly It is important to establish whether the problem under consideration is structured.

Reward system, considered in isolation from the nature of the relationship in a group, can not in itself provide an answer to the question of the extent to which this or that system affects the relationships in the group, the behavior of the group members, the functioning of the group as a whole. For example, it is impossible to evaluate the impact on a group of individual piece-rate payment, the collective-piecerate or payment based on a fixed budget group, if you do not know the nature of the activities of the group.

In the analysis of the effect of payment is important to consider at the same time two sets of factors: how interdependent actions of the group members;

how big differentiation in pay.

There are four possible combinations of these factors:

- Low interdependence - low differentiation in pay;

- Low interdependence - high differentiation in pay;

high interdependence-low differentiation in pay; high interdependence - high differentiation in pay.

The first and fourth cases give rise to many problems in the relationship between group members. In contrast, the second and third cases may contribute to the successful operation of the group and favorable development of relations between the members.

Human interaction and group are always of a bilateral nature; people with their work, their actions contribute to the solution of group tasks, but also the group has a significant influence on a person, helping it to meet its security needs, love, respect, selfexpression, identity formation, eliminate anxiety, etc. It is noted that in groups with a good relationship with an active intra-life people have better health and. better morale, they are better protected against external influences and work more efficiently than people who are in an isolated state or in "sick" groups affected by unresolved conflicts and instability. The group protects the individual, supports it and trains as the ability to perform tasks and the norms and rules of behavior in the group.

But the group not only helps a person to survive and improve their professional skills. It changes its behavior, making a person is often significantly different from what it was when he was out of the band. These impacts on human groups have many manifestations. Let us point out some significant changes in human behavior, taking place under the influence of the group.

First of all Under the influence of social changes take place such human characteristics, such as perception, motivation, attention span, scoring system, etc. Man expands its focus by increasing attention to the interests of other members of the group. His life is depending on the actions of his colleagues, and it significantly alters his view of himself, in his place in the environment and on others.

Secondly In a group of people receives a certain relative "weight". Group not only distributes the tasks and roles, but also determines the relative position of each. Members of the group can do exactly the same job, but at the same time have a different "weight" in the group. And it will be more important characteristic for the individual, which he did not have and could not have, being outside the group. For many members of the group, this characteristic may be no less important than their formal position. 


\begin{tabular}{|c|c|c|c|c|c|c|}
\hline \multirow{4}{*}{ Impact Factor: } & ISRA (India) & $=3.117$ & SIS (USA) & $=0.912$ & ICV (Poland) & $=6.630$ \\
\hline & ISI (Dubai, UAI & $=0.829$ & РИНЦ (Russia & $=0.156$ & PIF (India) & $=1.940$ \\
\hline & GIF (Australia) & $=0.564$ & ESJI (KZ) & $=8.716$ & IBI (India) & $=4.260$ \\
\hline & JIF & $=1.500$ & SJIF (Morocco & $=5.667$ & OAJI (USA) & $=0.350$ \\
\hline
\end{tabular}

Thirdly, group helps the individual to acquire a new vision of the "I". Man begins to identify with the group, and this leads to a significant change in his perception of the world, in the sense of its place in the world and his destiny.

Fourth While in the group, participating in discussions and decision-making, a person can also give suggestions and ideas that he would never have betrayed if comprehended the problem alone. The effect on the human "brain attack" significantly increases human creativity.

Fifth, It noted that in a group of people are much more inclined to take risks than in a situation where he has one. In some cases, this feature changes in human behavior is a source of more efficient and active behavior of people in the group setting, than if they acted alone.

Wrong to think that the band changed man as she wants. Often many influences from the band for a long time people resist, many effects he perceives only partially, some deny it completely. human adaptation process to the group and the group to adjust the person are mixed, complicated and often quite lengthy. Included in the group, entering into interaction with a group environment, people not only change myself, but have an impact on the group to other members.

Being in cooperation with the group, a man tries various ways to influence it, to make changes in its functioning so that it was acceptable to him, it is convenient to him and allowed him to cope with their responsibilities. Naturally, the shape of the impact and extent of human influence on the group essentially depend on the characteristics of his personality, his ability to influence, and on the characteristics of the group. A person usually express their attitude to the group from the standpoint of what he believes. However, his arguments are always depending on the position that it occupies in the group from performing their role, entrusted to it by the job and accordingly on what goals and interests he pursues personally.

Human interaction with the group could be either the nature of co-operation or merger, or conflict. varying degrees of symptoms can be observed for each form of interaction. That is, for example, we can talk about a hidden conflict, a weak or conflict of irresolvable conflict.

In the case of co-operation between a member of the group and the group established a trusting and supportive relationship. Man considers the purpose of the group it does not contradict its goals, it is willing to seek ways to improve the interaction is positive, albeit with rethinking their positions, accept group decisions and to find ways to maintain a relationship with the group on the basis of mutual benefit.

At the confluence of human the group observed the establishment of the relationship between man and the rest of the group, when each side views the other as organically united with it the whole component, which is a group. Man builds his purpose on the basis of group goals, largely subordinate its interests to those of the group and identify themselves with the group. The group, in turn, is also trying to look at the individual, not as a performer a certain role, but as a completely faithful person group. In this case, the group takes care of the person looking at his problems and difficulties as their own, trying to assist him in addressing not only the production problems, but to solve his personal problems.

In the event of conflict observed the opposition and human interest groups and the struggle between them for the resolution of this contradiction in their favor.

Conflicts may be generated by two groups of factors:

- organizational factors,

- emotional factors.

The first group of factors is related to the difference in the views on the target, structure, relationships, roles in the group and the so-called If a conflict is generated by these factors, it is relatively easy to solve.

The second group of factors include factors such as lack of confidence man, a sense of threat, fear, envy, hatred, anger, etc. Conflicts arising from these factors, little ability to completely eliminate.

The conflict between the group member and the group wrongly considered only as an adverse, negative state of relations in the group. Conflict assessment fundamentally depends on what consequences for humans and the group he leads. If the conflict is transformed into an antagonistic contradiction, the resolution of which is devastating for a person or a group, such a conflict must be attributed to the category of unwanted and negative forms of the relationship between man and the group.

But very often the conflict in relations within the group is positive. This is due to the fact that the conflict could lead to favorable results.

First, the conflict may increase motivation to achieve the goals. It can cause additional energy to the action, to bring a group of stable passive state.

Second, the conflict could lead to a better understanding of the relationship and position in the group * to the elucidation of the members of their role and place in the group, to a clearer understanding of the problems and the nature of the group.

Third, the conflict can play a constructive role in the search for new ways of functioning of the group, the search for new approaches to solving the problems of the group, in the generation of new ideas and suggestions on how to build relationships between group members, etc.

Fourth, conflict can lead to the manifestation of interpersonal relationships, to identify relationships between individual members of the group, which in turn can prevent possible negative aggravation of relations in the future. 


\begin{tabular}{|c|c|c|c|c|c|c|}
\hline \multirow{4}{*}{ Impact Factor: } & ISRA (India) & $=3.117$ & SIS (USA) & $=0.912$ & ICV (Poland) & $=6.630$ \\
\hline & ISI (Dubai, UAI & $=0.829$ & РИНЦ (Russia & $=0.156$ & PIF (India) & $=1.940$ \\
\hline & GIF (Australia) & $=0.564$ & ESJI (KZ) & $=8.716$ & IBI (India) & $=4.260$ \\
\hline & JIF & $=1.500$ & SJIF (Morocco & $=5.667$ & OAJI (USA) & $=0.350$ \\
\hline
\end{tabular}

One of the main results of the interaction between man and the organization is that people, analyzing and evaluating the results of their work in the organization, revealing the causes of successes and failures in the interaction with the organizational environment, analyzing the experience and behavior of their colleagues, reflecting on the advice and recommendations of superiors and colleagues, make certain conclusions, which in one way or another affect his behavior, leads to a change in his behavior in order to adapt to the organization, in order to achieve the best in interacting ones with the organizational environment.

\section{Learning Behavior in Organizations}

It is obvious that the perception and evaluation of his experience, as well as the process of adaptation to the conditions and requirements of the organizational environment in many ways have individual character. In the same environment, people behave differently. In humans, as it has two degrees of freedom in the construction of their behavior in the organization. On the one hand, he has the freedom in the choice of forms of behavior: to take or not to take existing in the organization forms and norms of behavior, on the other - he can accept or not accept values of the organization, to share or not to share its goals and philosophy. Depending on what combinations of these fundamental components are combined behavior, four limiting types of behavior in the organization may be allocated.

The first type: Fully accepted the values and norms of behavior. In this case, a man tries to behave in such a manner that their actions can not be in contradiction with the interests of the organization. He sincerely tries to be disciplined, to fulfill its role in full in accordance with the organization's rules and behaviors. Therefore, a man of action results is largely dependent upon his or her personal capacity and capabilities, and how to correctly determine the content of his role. This type of behavior can be described as the behavior of a dedicated and disciplined member of the organization.

The second type Man does not accept the values of the organization, however, he tries to behave completely following the norms and behaviors taken by the organization. Such a person can be described as opportunists. He does everything right and according to the rules, but it can not be considered a reliable member of the organization, as although he is a good and an executive employee, however, may at any time to leave the organization or to perform actions that may conflict with the interests of the organization, but the match his own interests. For example, such a person would be willing to participate in a strike in order to get a pay raise.

The third type Man accepts the organization's values, but does not accept the existing norms of behavior in it. In this case, a person can produce a lot of difficulties in relationships with colleagues and management, it looks like the original. However, if an organization can afford to give up well-established standards of conduct in relation to its individual members and to create a state of freedom of choice of forms of conduct for such members, they can find their place in the organization and bring her favor.

The fourth type: The individual does not accept any code of conduct or the organization values. This is an open rebel who always is in conflict with organization nym environment and creates conflict. It would be wrong to assume that this type of behavior is absolutely unacceptable in the organization and the people who behave in this way, do not need an organization. However, in most cases, the "rebels" give rise to many problems which greatly complicate the life of the organization, and even cause her great harm.

Naturally, the organization is interested in the fact that its members behave in a certain way.

A possible approach to solve this problem - is the selection of people with certain qualities that can ensure the desired behavior for the organization of its members. However, it should be recognized that this approach is of limited use, because in the first place, is not always possible to find people with the necessary characteristics, and secondly, there is no absolute guarantee that they will behave necessarily so, how to expect the organization, and thirdly, the requirements to the behavior of members of the organization from the organizational environment can change over time, coming into conflict with the criteria on which people were taken to the organization.

The second approach Does not exclude the first, in principle, it is that the organization affects the person, causing him to modify his behavior in the right direction for her. This approach is possible and is based on the fact that a person has the ability to study behavior, change their behavior based on awareness of their previous experience and behavioral requirements for his behavior on the part of the environment.

Learning behavior can be described as sufficiently stable during the process of changing the time of human behavior based on experience, the reflecting action of man and environment response to these actions.

For teaching behavior is characterized by a few moments.

First of all, Learning can go both on their own experience and the experience of others.

Secondly, learning behavior does not necessarily refers only to actual real behavior. It may relate to the potential behavior, ie such behavior, which can be accomplished by man, but that is not done by him in his practice behavior.

Thirdly, Learning behavior is always expressed in the change of the person. Even in the case where the 


\begin{tabular}{|c|c|c|c|c|c|c|}
\hline \multirow{4}{*}{ Impact Factor: } & ISRA (India) & $=3.117$ & SIS (USA) & $=0.912$ & ICV (Poland) & $=6.630$ \\
\hline & ISI (Dubai, UAI & $=0.829$ & РИНЦ (Russia & $=0.156$ & PIF (India) & $=1.940$ \\
\hline & GIF (Australia) & $=0.564$ & ESJI (KZ) & $=8.716$ & IBI (India) & $=4.260$ \\
\hline & JIF & $=1.500$ & SJIF (Morocco & $=5.667$ & OAJI (USA) & $=0.350$ \\
\hline
\end{tabular}

direct behavior has not changed, people have become different as it changes its behavior potential.

There are three types of learning behavior.

The first type associated with reflex behavior of a person, that is named teachings Pavlov conditioned and unconditioned reflex. If, for example, the chief comes to subordinates when he was dissatisfied with something, annoyed, and intends to make it a reprimand, then every occurrence officer may cause fear in subordinates, the desire to avoid this meeting, no matter why he came to them. That is, the appearance of the Chief develops reflex desire to hide from his eyes.

The second type of learning behavior It based on the fact that people draw conclusions from the consequences of his previous experience, consciously adjusts and changes its behavior. The theoretical description of this type of learning is based primarily on research B. Skinner, who laid the foundations of the theory of engagement implemented behavior depending on its consequences. The essence of this theory is to ensure that if a person sees that his behavior leads to favorable outcomes, then it tends to repeat this behavior, if the consequences are negative, the desire to behave in a similar manner and then will be substantially reduced. That is, a person's behavior is defined by conscious comprehension of the results of the previous behavior.

The third type learning behavior - it's learning by observing behavior. Usually it is the observation of another's behavior. Man watching regularly, the behavior of the people around him, automatically starts to adjust their behavior to their own behavior. He adopts their style and manners of operations skills, etc.. Often carried targeted observation of another behavior to adopt themselves to something useful. With the development of tools video object expand surveillance capabilities and, in particular, expanding the object of observation. Now people can view, record their own behavior, which can also significantly influence the adjustment of behavior. It is obvious that all three types of learning behavior must be taken into account by management in its efforts to adjust and shape the behavior of the members of the organization.

What is studying people in the organization, which aspects of its behavior are adjusted or changed in the process of learning?

First of all He came to the organization and further carrying out their activities in it, people learn their respective roles: what he should do for the best performance, how to implement more effectively the work, how and with whom to communicate on the job. At the same time he learns to highlight key points in the work carried out by them in terms of what is considered to be the organization more important and what is less important in its activity, for which there is a fee that is included in the assessment of the quality of his work.
Secondly, in the organization of a person learns to implement formal and procedural actions, such as filling out various questionnaires and forms processing applications, appointment and meetings, transfer, acquisition and implementation of the response to the information received, the temporary abandonment of the workplace, the arrival and departure from work, parking car, wearing a certain type, etc.

Thirdly, man learns to understand and take its place in the organization. He learns that exist in the organization's norms, values and established on the basis of their informal groups and relationships, learns to behave with colleagues and management, defines for itself with whom to have a close relationship and who to steer clear whom to trust, whom to rely, and who fear.

Fourth, a person learns how to solve their own problems in the organization, how to achieve their goals. For example, he learns how to make a career in the organization. Or how to achieve certain incentives and rewards. Can people learn and how to harness the power of the organization or the possibility of its individual members to solve their personal problems are not related to the activities of the organization. The employee can learn how to avoid the difficult and risky job, and even how to doing nothing, to create the appearance that he is working hard.

In order to describe the process of conscious learning of human behavior in organizations, and to point out the connection of this process with the management of the person in your organization, consider in a general way a few basic elements that determine human behavior in organizations. The details of these elements will be considered when considering the question of motivation.

Human activity is always connected and it is initiated by the presence of specific inducing started. They forced him to start to do something, to take some effort, ie, taking action. Incentives that are external effects on humans, its work is directed in a certain way, give this activity a certain orientation and boundaries. Human behavioral response manifested in the fact that he chooses what and how to do, and taking concrete actions leading to concrete results. His reaction is strongly linked to incentives. However, it has an individual character, since it reflects the varying degrees of incentives to influence the behavior of different people. human reaction can manifest itself in the form of its specific actions, and as they develop a certain location. Depending on the effects on human behavioral responses it is fixed with the aim of strengthening and giving it stability or else fails it. Securing implemented behavior or waived play a very important role in shaping human behavior, because it is through this is a conscious adjustment or even a change of behavior in the desired direction for the organization. 


\begin{tabular}{|c|c|c|c|c|c|c|}
\hline \multirow{4}{*}{ Impact Factor: } & ISRA (India) & $=3.117$ & SIS (USA) & $=0.912$ & ICV (Poland) & $=6.630$ \\
\hline & ISI (Dubai, UAI & $=0.829$ & РИНЦ (Russia & $=0.156$ & PIF (India) & $=1.940$ \\
\hline & GIF (Australia) & $=0.564$ & ESJI (KZ) & $=8.716$ & IBI (India) & $=4.260$ \\
\hline & JIF & $=1.500$ & SJIF (Morocco & $=5.667$ & OAJI (USA) & $=0.350$ \\
\hline
\end{tabular}

Thus, a change in human behavior can be seen as a consequence of learning behavior. Itself, the learning behavior is a function of consequences of human actions made by him, the function of the consequences of his behavior. The presence of such a relationship between the behavior, by teaching behavior and the consequences for the person's behavior makes it possible for the organization to adjust and shape the behavior of its members. This is due primarily to the fact that management and organizational environment can define and purposefully form for members of his organization the consequences of their behavior, is actively involved in the process of learning behavior at the stage of human impact of the implementation of certain actions.

Learning and behavior modification of human behavior in organizations

Obviously, the consequences of actions depend on how people behaved, what he was doing. However, they directly depend on those who, appreciating the human action, compensates for his actions and efforts. In this case, compensation is understood in the broadest sense as an external reaction to the behavior of man, manifested in the fact that a person or something gets or loses something, achieve something or something does not reach as a result of them, the form of a certain behavior action. Payment can be made in various forms - from the material rewards or punishment to verbal approval or condemnation. Compensation plays an extremely important role to be taught behavior, since it has a major influence on whether there is consolidation carried out by the behavior occurs or waived. If there is no compensation that causes the human understanding of the consequences of his actions, in fact no noticeable behavior modification, as there is no learning behavior. Therefore, compensation for the management of people plays not only the role of remuneration for work produced a role means to meet the needs of employees, but also the role means for modifying human behavior.

If you look for compensation from the standpoint of learning behavior and behavior modification, the four different types of compensation can be identified, which lead to consolidation or renounce implemented behavior.

The first type- this is a positive compensation. The essence of this type is that the fee is carried out, resulting in a pleasing to the human consequences. Form of compensation may be quite different. Positive compensation may be used by the leadership to consolidate the desired behavior of employees. It is important to take into account that the remuneration must be clearly linked to the desired behavior, ie People need to know why he got a promotion. Remuneration should be followed for the implementation of the desired behavior and, finally, remuneration must correspond to the interests of promoting the human.

The second type - is a negative compensation. The essence of this type is that the desired behavior immediately leads to elimination is not desirable for the human circumstances or stimuli. For example, a person who does not behave properly exposed boycott others. As soon as he starts to behave correctly, in terms of the environment, they stop the boycott. In the second type of compensation, as well as the first time, it is important that the reaction environment or lead to changes in the behavior of advancing as quickly as possible and, of course, was of individual character.

The third type compensation is punishment. In this case, unlike the first two types of compensation comes as a reaction to the "wrong", or undesirable to guide the behavior of organizations.

If the first two types of fixed desired behavior, in this case eliminated the unwanted behavior. Compensation in the form of punishment are a member of that person receives a negative, unpleasant consequences for his behavior. For example, it can be fined, lose bonuses or promotion at work, get the comment, etc. The task of punishment is to narrow or eliminate undesirable behavior for the organization of its members. Although punishment externally looks the exact opposite of the positive compensation - there is reward, here take - in terms of learning human behavior is not. This type of compensation less effect than a positive compensation. This is due to the fact that the punishment is less predictable and stable effect than promote, often leads to an indirect negative effects, such as a personal insult to punish the head, loss of interest in work, a change of attitude in their activities, etc. Therefore, the punishment as a way of compensating for the purpose of learning behavior management should be treated very carefully and closely monitor its possible negative side manifestations.

The fourth type of compensation- quenching is undesirable behavior; The essence of this type of compensation is as follows. The person carrying out any unwanted actions, which previously acted positive reaction, stop them after a while, if these actions are positive reaction ceases to act, ie, in other words, if you stop to respond favorably to any action, they will begin to shrink after a while. For example, young people who have successfully studied in the university and receives praise teachers for active performance in the classroom and comment on the performances of their colleagues came to work in the organization, it will also try to meddle in all discussions and conversations and to give their comments and assessment of applications other. However, if it does not pay attention, then after a while it will start to get rid of this bad habit. The choice of the type and specific forms of compensation plays a very important role in the successful 


\begin{tabular}{|c|c|c|c|c|c|c|}
\hline \multirow{4}{*}{ Impact Factor: } & ISRA (India) & $=3.117$ & SIS (USA) & $=0.912$ & ICV (Poland) & $=6.630$ \\
\hline & ISI (Dubai, UAI & $=0.829$ & РИНЦ (Russia & $=0.156$ & PIF (India) & $=1.940$ \\
\hline & GIF (Australia) & $=0.564$ & ESJI (KZ) & $=8.716$ & IBI (India) & $=4.260$ \\
\hline & JIF & $=1.500$ & SJIF (Morocco & $=5.667$ & OAJI (USA) & $=0.350$ \\
\hline
\end{tabular}

modification of human behavior in the desired direction for the organization.

However, an equally important role played by the choice of frequency compensation to guide learning behavior. In general, there may be two approaches to the timing of compensation.

one approach- is the payment after any human action. This approach is called continuous compensation.

Other Fundamentally different approach to timing and frequency compensation is that compensation does not occur after every act done. This periodic compensation. Although between these two approaches, there is a fundamental difference, we can not say which one is more effective, because their effectiveness depends significantly on the situation in which they are applied. At the same time it is noted that the first approach better effect in the case where it is applied to a new employee, trainee its role in the organization. The second approach is best used when the organization wants to make certain stable behavior of its members.

As part of the periodic compensation are four different types.

The first type - is payment through a fixed time interval. This approach suffers from the disadvantage that the desired behavior of workers is shown uneven, growing at those moments when fixing is carried out or payment, and decreases in the gaps between them.

The second type-compensation via the variable time interval. In this case, the interval between the potential compensation and frequency compensation is not fixed. This approach is not applicable to all forms of compensation. However, he gives the best results, since an unspecified time compensation keeps the tension and makes the work better and behave. Although the sharp decline may occur after the compensation for the organization in the desired behavior of its members.

The third type Unlike the first and second basis for not taking the time interval and the volume of action. This type is called a compensation depending on the fixed rules. With this approach, the payment comes after made some sort of a fixed number of actions. Experience shows that this type of compensation gives better results in the formation of behavior than the first and second types of periodic compensation.

The fourth type(Last), based also has a compensation | Depending on the amount of action. However, this compensation depending on the variable rate. This approach is considered to be highly effective, because compensation can occur after any individual action that encourages employees continuously implement the "right" action. In order for this approach gave really good results in the modification of behavior, it is important that the time intervals between compensation were not very large. At the same time you must know that this approach is of limited use. For example, it is hardly applicable to this form of payment, such as wages.

Considered questions of learning behavior say that people, based on its experience, adapted to the organizational environment, changing their behavior. The organization and its management can actively influence the modification of human behavior. However, the means used to influence the process of learning behavior and the frequency of their use depends on the situation in which there is a person, and should be selected taking into account the manager all the variety of factors affecting human behavior. First and foremost the needs and motives to human action.

The process is characterized by four theories of motivation, creating a basis for motivation.

expectations theory: expectation in the chain "execution efforts"; waiting in the chain "performance - the result"; valence of the outcome.

The theory of goal setting. Four target characteristics: complexity, specificity, acceptability and commitment.

The theory of equality: a comparison of their results with the results of other actions.

The concept of participatory governance.

The most common concept of motivation process is reduced to the following provisions. The man, realizing the problem and possible compensation for their decision, relates this information to their needs, motivational structure and opportunities, setting yourself up for a certain behavior, produces a specific location and implemented an activity leading to a specific result, characterized by certain qualitative and quantitative characteristics.

This scheme does not disclose any further compensation mechanism proper remuneration audio content, nature and content ratings, or ratings in the conversion solution. The modern management thought and practice, there are a number theory, which are sufficiently detailed and on an operational level, describe the process of motivation. The most famous of them - it's - expectations theory, the theory of goal setting, equality theory and the theory of participatory governance. They tried to explain why people are willing to carry out certain actions, spending more or less force. And by explaining it, they give managers the key to building an effective system of motivating people, ie. E. How to influence people, to encourage them to productive work.

Human behavior is constantly connected with the choice of two go several alternatives. From what a man gives a particular preference depends on how and what it does, how it behaves and what he achieves results. expectations theory has been developed to provide an answer to the question why a person does this or willow choice when faced with several alternatives, and how he is motivated to achieve results in accordance with the choice made. In the most general form of the expectations theory can be 


\begin{tabular}{|c|c|c|c|c|c|c|}
\hline \multirow{4}{*}{ Impact Factor: } & ISRA (India) & $=3.117$ & SIS (USA) & $=0.912$ & ICV (Poland) & $=6.630$ \\
\hline & ISI (Dubai, UAI & $=0.829$ & РИНЦ (Russia & $=0.156$ & PIF (India) & $=1.940$ \\
\hline & GIF (Australia) & $=0.564$ & ESJI (KZ) & $=8.716$ & IBI (India) & $=4.260$ \\
\hline & JIF & $=1.500$ & SJIF (Morocco & $=5.667$ & OAJI (USA) & $=0.350$ \\
\hline
\end{tabular}

formulated as a theory describing the dependence of motivation on two things: how many people would like to get and how much is possible for him to get what he sought, in particular, how much effort he is prepared to spend for it. For example, a beginner businessman from the provinces arrives for talks about the beginning of the joint business with representatives of major companies located in the city is recognized as a center of business activity. it will not stay at the hotel to maintain its reputation, has a reputation as a second-rate, although it is cheap. At the same time he does not have the means to stay in a posh hotel. Therefore, apparently, it will stop in this hotel, which is quite prestigious and accommodation in which he has enough money.

Process motivation for standby theory formed as through the interaction of three blocks: 1) effort; 2) performance; 3 ) result. expectation theory studies and describes the interaction of these three blocks. At the same time efforts are seen as a consequence of, or even the result of motivation. Execution is considered - as a consequence of the interaction of forces, personal capabilities and state of the environment, and the result, as a function that depends on the performance and the degree of desire for the results of a certain type.

expectations theory explains how the process of human motivation is based on activities on the basis of linking into one representation ions of human needed to perform the work efforts, its practical implementation and the results expected in response to the work performed. In this case, the key points of focus of the theory are: 1) expectations for a chain "effort - performance"; 2) Waiting for "execution of the chain - of a second level, and 3) the valency results.

According to the expectations theory, the motivation of the person to the executing eniyu work depends on whether he is interested or not interested to carry out her work as attractive to him. Making a decision about what to do and how much effort to expend, the person usually responsible himself to the question concerning the extent necessary for him to do so. That is the choice of an alternative person thinks about if he will behave accordingly, will be properly perform the work, whether this will lead to a certain result of the first level. In this case, it is formed waiting for results of the first level. In addition, the person answering the question of what he will receive as a result of successful completion of the work.

This is the development of waiting for a secondlevel results. Finally, he decides for itself how valuable this will result for him, ie, it evaluates valence result of the second level. Depending on to which the final evaluation of man comes, will be shaped his motivation to do the work.

The main provisions of the theory of expectations are as follows.
First of all, as this theory is subordinated to the idea of looking for an answer to the question how motivation affects the performance of the work, the initial postulate is that the performance is determined by the product of the two factors: human potential and motivation.

Secondly, argues that the motivation given by the product carried I chin waiting results of the first level by an amount valency results of the first level. And finally,

Third, valency results given by the product of the first level value valency results of the second level to the standby individual results of the second level. Man chooses the alternative, which would be higher motivation.

Using various techniques, the manager for the successful management subordinates to build management of the organization so that the worker was confident that by working to achieve organizational goals, he thereby creates conditions for achieving the best results of the second level.

The expectations theory holds that in order to able to carry out process of motivation, should be carried out a number of preliminary conditions. These conditions are:

- the presence of workers are sufficiently high degree of expectation of the first level of results;

- the availability of sufficiently high expectations of the results second level and

- a non-negative total valence of the results of the second level.

In practice, this means that the employee must have a firm understanding of the fact that by his efforts depend on the results of his labor, that the results of his work entails certain consequences for him, and that the results obtained by them in the end, have to his value. In the absence of one of these conditions of the process of motivation becomes extremely difficult or even impossible.

Making the overall conclusion about the theory of expectations, it should be noted that it is based on the fact that people perform their activity in accordance with the order to which the possible consequences for them, these actions can cause. People on the basis of information available to them make the choice of one of the alternatives of action, based on the fact that they will receive as a result and how much effort they will have to be expended to achieve that result. That is, the theory of expectations, the person behaves in accordance with the fact that, in his opinion, will happen in the future if it will generate some costs of efforts.

The theory of goal setting comes from the fact that human behavior It is determined by the objectives which it set itself, as it is for achieving the goals before it performs a specified action. It is assumed that setting goals - is a conscious process and conscious goals and intentions - that is what lies at the basis of the definition of human behavior. 


\begin{tabular}{|c|c|c|c|c|c|c|}
\hline \multirow{4}{*}{ Impact Factor: } & ISRA (India) & $=3.117$ & SIS (USA) & $=0.912$ & ICV (Poland) & $=6.630$ \\
\hline & ISI (Dubai, UAI & $=0.829$ & РИНЦ (Russia & $=0.156$ & PIF (India) & $=1.940$ \\
\hline & GIF (Australia) & $=0.564$ & ESJI (KZ) & $=8.716$ & IBI (India) & $=4.260$ \\
\hline & JIF & $=1.500$ & SJIF (Morocco & $=5.667$ & OAJI (USA) & $=0.350$ \\
\hline
\end{tabular}

In total, a base model that describes the process of setting objectives, as follows. Man given emotional reaction is aware of and assess events occurring in the environment. On this basis, it determines the goals for yourself to achieve that he intends to seek, and, based on the goals, it performs certain actions - performs a specific job. That is behaving in a certain way, it has reached a certain result and receives from this satisfaction.

Goal setting theory states that the level of performance of the work, directly or indirectly, to a large extent depends on the characteristics of the four purposes:

- complexity;

- specificity;

- acceptability;

- commitment.

These four characteristics of the target is influenced by both the target itself, and on the efforts that a person is willing to spend in order to achieve its goal.

The complexity of the target It reflects the degree of professionalism and the level of performance required to achieve it. There is a direct relationship between the complexity of the objectives and implementation of the work. The more complex the goal set itself the person, the better results it achieves. An exception is the case when the set goals unrealistically high, which in principle can not reached. $\mathrm{V}$ this case, according to the theory of goal setting, action result does not exceed the result sought by those who put a moderate, but achievable goals. Therefore, improving the objectives, although it is justified, may lead to an increase in labor results only if there was a chance of achieving the goals.

Target specificity It reflects quantitative clarity of purpose, its accuracy and certainty. Experimental studies have shown that the more specific and defined goals lead to better outcomes for the better execution of work than the target, having a broader meaning, with clearly defined content and boundaries. A person who has goals too broad meaning and content, demonstrates the same performance of the work, as well as someone who has absolutely no purpose. At the same time, too much narrowing of goals can lead to the fact that behind the consideration of a person may remain important aspects of its operations. It also has a negative impact on the performance of their work.

Acceptable purpose It reflects the degree to which a person perceives the goal as his own. Acceptability goal exerting a significant impact on how the impact on the performance of work and the complexity of the target specificity. If a person does not accept the target, and the complexity and specificity of the target will have very little effect on the performance of the work. Acceptability goal man depends on whether it is perceived by him as achievable, and what kind of benefits it can get to achieve the objective. If the benefits are not obvious, the purpose can not be accepted. Therefore, the management of the organization must be a clear understanding of the significance and the importance of the actions that would make the goal achievable, reasonable, fair and safe in employee representation.

Commitment to It reflects the willingness to expend effort a certain level to achieve the goal. It is very important for the level; and quality performance targets feature, as it can play a decisive role on the stage of execution, if the reality, difficulty performing work to differ materially from what they presented at the goal setting stage. Commitment to the goal may increase as the performance of the work, and may drop. Therefore, management must continually monitor the level of commitment to the part of workers and take the necessary measures to maintain it at the proper level.

In theory, setting goals when considering performance, depending on the purpose of emphasizes that the quality of performance depends not only on the defined purpose of the efforts of the worker, but also on two groups of factors: 1) organizational factors, and 2) the ability of the employee. The data groups of factors can influence not only the quality and performance of content, but also on the target, thereby providing an indirect effect on the motivation and therefore additional impact performance. For example, if the present weak feedback from the results of labor, it can reduce the degree of influence on the target employee efforts to implement the work.

The final step in the process of motivation theory of goal setting is the result of employee satisfaction. The special significance of this step is that it not only completes the chain motivation process, but also is the starting point for the next cycle of motivation.

The theory states that if the actions produced a positive result for the subject, he gets satisfaction if negative - the disorder. In this goal-setting theory states that satisfaction or dissatisfaction is determined by two processes: internal to the individual processes and external.

Internal processes, leading to satisfaction, mainly related to how a person evaluates his results in terms of its correlation with the intended purpose. If the goal is achieved, to fulfill its task, the person feels a sense of satisfaction. If not, then it causes dissatisfaction. This circumstance gives rise to a tension in the target setting. As already mentioned, the higher and more complex target, the higher the level of performance. At the same time, the high goal can lead to the fact that it will not be achieved with a greater probability, and therefore, people will feel a sense of dissatisfaction and frustration. This in turn can lead to a desire - to take the lower target, or refuse to make complex setting goals. It is therefore important at the stage of setting goals is very serious approach to this issue. 


\begin{tabular}{|c|c|c|c|c|c|c|}
\hline \multirow{4}{*}{ Impact Factor: } & ISRA (India) & $=3.117$ & SIS (USA) & $=0.912$ & ICV (Poland) & $=6.630$ \\
\hline & ISI (Dubai, UAI & $=0.829$ & РИНЦ (Russia & $=0.156$ & PIF (India) & $=1.940$ \\
\hline & GIF (Australia) & $=0.564$ & ESJI (KZ) & $=8.716$ & IBI (India) & $=4.260$ \\
\hline & JIF & $=1.500$ & SJIF (Morocco & $=5.667$ & OAJI (USA) & $=0.350$ \\
\hline
\end{tabular}

External process Affecting the satisfaction or dissatisfaction with the results of man is Xia processes reactions to the results of work on the part of the environment, evaluation of performance environment. If the environment responds positively (thanks to management, promotion, pay increase, the praise of colleagues, etc.), it is a source of satisfaction, if not, it leads to dissatisfaction.

External processes also encompass a controversial start, rendering a dual impact on support of motivational process in an efficient, in terms of quality and performance level state. The essence of this contradiction lies in the fact that a person is behaving in accordance with the objectives and the evaluation of its actions most often based on the results of execution. Therefore, if a person achieves these goals, but it demonstrates a low level of performance, moderate or even negative external evaluation may lead to a very strong frustration and a sharp drop in motivation to continue the action. Just adversely on the motivational process can affect the positive external evaluation of successful execution, provided that the person is not able to achieve their goals. This leads to a decrease in commitment to the goals and, ultimately, a negative impact in the future on the quality and level of performance of the work. Foot achievement is to set a simple goal, which will necessarily have a negative impact on the quality and level of performance.

General recommendations for the implementation of goal-setting process can be summarized as follows.

first, You need to determine the extent to which the organization and the people who work in it, ready to implement goal-setting process.

second, if the organization has readiness potential, it is necessary to carry out a number of measures for the introduction of practical training goal setting process.

third, goal setting should be underlined their complexity and specificity, and taking into account the purposes of admissibility, and adherence to them.

fourth, necessary to carry out an interim analysis of the goals and adjust them.

fifth, req Dimo analyze the objectives, summarize the results of the previous steps and make recommendations for further implementation of the goal setting process.

One of the constant pursuit of people is the desire to get a fair assessment of their actions. People, though not to the same degree, want to be treated fairly. In this case, justice is associated with equality, as compared with the relation to the other and evaluate their actions. If a person believes that it is approached in the same way as others, without discrimination, evaluate his actions from the same positions as the actions of others, it feels right to do with himself and feels satisfied. ECDo the same equality is violated if the individual members of the organization receive undeserved praise and reward, the person feels hurt, and this leads to frustration and dissatisfaction. In this dissatisfaction can occur even when a person gets high in relation to its cost of labor remuneration. The effect of the moment on the human relationship with the organization as the basis of a motivational process theories - equality theory.

The theory of equality comes from the fact that in the process of comparison, although it uses objective information, for example, the value of Zara and salaries, the comparison is performed by man on the basis of his personal perception and their actions, and actions of people with whom he compares.

Norma - the ratio of the perceived cost to the perceived reward. There are two types of norms. The norm of the first type represents the ratio of the sensed individual compensation to the perceived cost of the individual. Norm of the second type It reflects the attitude of the perceived rewards to other perceived cost of others.

The theory of equality says that the person is very important as it relates to norms with others. If the rules are, man, even at a lower remuneration, feels justice, as in this case, there is equality. If it is below the norm, he believes that his reward enough. If its rate is higher, he believes that his reward too.

Taking place in the management practices of the view that inequality encourages people to increase the Performing result that the state of equality discourages people to do more, is wrong in principle. As stated in the theory of equality on the basis of empirical studies carried out, the person feels a sense of satisfaction, if enforced equality. Therefore, it is committed to maintaining this state.

Equality is bad when the overall level of performance is low. In this case, equality will lead to the preservation of this level. If, however, the overall level of performance is high, the equality is an important motivating factor for the success of members organization.

In that case, if an individual believes that he is rewarded with insufficient accurately or too, he has a sense of dissatisfaction (in the second case this feeling is less pronounced). Considering the unfair and unequal appraisal of his work, the person loses the motivation to active creative in terms of the organization's objectives, action that leads to many negative consequences.

The theory of equality leads to some very important you vodov for people management practices within the organization. Since perception is subjective, it is very important that was widely available information about who, how, what, and how many receive remuneration. It is particularly important that there be a clear payment system to answer questions about what factors determine the amount of payment. An important conclusion of the theory of equality is that people are guided by a comprehensive assessment of remuneration. 


\begin{tabular}{|c|c|c|c|c|c|c|}
\hline \multirow{4}{*}{ Impact Factor: } & ISRA (India) & $=3.117$ & SIS (USA) & $=0.912$ & ICV (Poland) & $=6.630$ \\
\hline & ISI (Dubai, UAI & $=0.829$ & РИНЦ (Russia & $=0.156$ & PIF (India) & $=1.940$ \\
\hline & GIF (Australia) & $=0.564$ & ESJI (KZ) & $=8.716$ & IBI (India) & $=4.260$ \\
\hline & JIF & $=1.500$ & SJIF (Morocco & $=5.667$ & OAJI (USA) & $=0.350$ \\
\hline
\end{tabular}

Remuneration plays an important role in this comprehensive assessment, but not the only, and are not necessarily decisive. Therefore, managers should take this into account if they are trying to create, an atmosphere of equality in the team.

As repeatedly stressed, the perception of equality and justice is strongly pronounced subjective character. For successful people management manager should not only strive to be fair, to create an atmosphere of equality, but also good to know if workers believe that the remuneration is based on a fair and equitable basis. To this end, management should conduct research on a regular basis with a view to ascertaining estimated compensation of employees, whether they believe it or not equal.

The man in the organization manifests itself not only as a performer particular job or a particular function. He is interested in how to organize its work, the conditions in which it works, how it affects the work of the organization. That is, it has a natural tendency to participate in the proceeding in the organization of the processes that are associated with its activities in the organization, but it is beyond the scope of its competence, the scope of its work and tasks of the department.

Participative Management Concept comes from the fact that if a person is interested in the organization is involved in various corporate activities, it thus getting from this satisfaction, working more efficiently, better, more efficiently and productively. Firstly, it is believed that the participative management, employee opening the access to decision-making about issues related to its functioning in the organization, motivating a person to better perform his job. Second, participative management not only helps to ensure that a worker does a better job with their work, but also leads to a greater impact, greater contribution of the individual employee in the organization of life, ie, is more full use of the capacity of human resources of the organization.

Initially, participatory control the spread was linked only to the improvement of employees' motivation. More recently, participatory governance is increasingly associated with the improvement of the full potential of human resources of the organization. Therefore, the concept of management partisipativnogr can not be attributed only to the motivation process, and should be considered as one of the common approaches to the management of the person in the organization.

Participative management can be implemented in the following fields.

First of all, workers have the right to make their own decisions about how to implement them its activities. Independence can relate to, e.g., of aspects of their activity as ily operation mode selection means of the operation.

Secondly, employees may be involved in the decision about the work they do. In this case, the head consults with the employee about what he to do and how to carry out its tasks. That is, in other words, an employee is involved in setting goals that he had to reach, identifying the challenges that it will have to be addressed.

Thirdly, employees are given the right to control the quality and quantity of work carried out by them and thus establishes the responsibility for the final result.

Fourth, participative management requires broad participation of employees in innovation, and in making suggestions for improving their own work and the work of the organization as a whole and its individual units.

Fifth, WHO possible direction of participatory governance is to provide workers the right to form working groups of the members of the organization with whom they would like to work together. In this case, it is given the right to make decisions not only about their own working member of the organization, but also about the person with whom to cooperate in group activities.

In actual practice all of these areas of participative management commonly used in certain combinations, since they are very closely related to each other and very highly complementary. Moreover, it is in combination with each other, these separate areas can be efficiently pro manifest themselves, and that the individual settled combination of these directions are used as concrete forms participative management. The most obvious example of this are quality circles, it is widely used in the management of Japanese companies.

\section{Conclusion}

The person performs some action in accordance with the pressure on it together the internal and external with respect thereto forces. The combination of these forces, called motivation, is by no means the same reaction in humans. Therefore impossible you can clearly describe the process of motivation. At the same time, on the basis of empirical studies have developed several concepts that describe the factors that influence the motivation and the content of the motivation process.

The so-called theory of the content of motivation have focused on how the needs of different groups of influence on human behavior. It is widely accepted the concept of this group are the theory of Maslow's hierarchy of needs, ERG theory Alderfera theory Herzberg's two-factor theory, and when McClelland newfound needs. Despite the fundamental differences between these concepts, they nevertheless have something in common in their basis, which reflects a certain commonality in the human motivation to take action.

motivation process disclosed in the theories attempting obyas thread, why people are willing to carry out certain actions, spending more or less force. 


\begin{tabular}{|c|c|c|c|c|c|c|}
\hline \multirow{4}{*}{ Impact Factor: } & ISRA (India) & $=3.117$ & SIS (USA) & $=0.912$ & ICV (Poland) & $=6.630$ \\
\hline & ISI (Dubai, UAI & $=0.829$ & РИНЦ (Russia & $=0.156$ & PIF (India) & $=1.940$ \\
\hline & GIF (Australia) & $=0.564$ & ESJI (KZ) & $=8.716$ & IBI (India) & $=4.260$ \\
\hline & JIF & $=1.500$ & SJIF (Morocco & $=5.667$ & OAJI (USA) & $=0.350$ \\
\hline
\end{tabular}

expectations theory, the theory of goal setting, equality theory and the theory of participatory governance, explaining that how to influence people, to encourage them to productive work, give managers the key to building an effective system of motivating people.

\section{References:}

1. Prohorov, V. T., et al. (2017). Concept import light industry: background, objectives, innovations: monograph. Under the total. Ed. Dr. tehn. Sciences, prof. VT Prokhorov (Eds.). (p.334). Institute of Entrepreneurship and Service sector (branch) of the Don State Technical universitety of Mines: ISOiP (branch) of Dagestan State Technical University.

2. Kompanchenko, E. V., et al. (2015). Advertisement as a tool for the promotion of the philosophy of quality production of competitive products. Under the total. Ed. prof. VT Prokhorov (Eds.). (p.623). Institute of Entrepreneurship and Service sector (branch) of the Don State Technical University of Mines: ISO and P (branch) of Dagestan State Technical University.

3. Prohorov, V. T., et al. (2014). Quality Revolution: quality through advertising or through real quality: monograph. Under the total. Ed. prof. VT Prokhorov (Eds.). ISOiP (branch) DSTU. (p.384). Novocherkassk: YURGPU (NPI).

4. Prokhorov, V. T., et al. (2015). The range and assortment policy: monograph. Under the total. Ed. Dr. tehn. Sciences, prof. VT Prokhorov (Eds.). Institute of Entrepreneurship and Service sector (Phil.) Feder. state. budgets. obrazovat. postsecondary institution. prof. Education "Don State. tehn. Univ "in Mining Height. region. (ISOiP (branch) DSTU). (p.503). Novocherkassk: YURGPU (NPI).

5. Prokhorov, V. T., Aspen, T. M., Reva, D. V., Duyun, L. V., \& Zverev, S. M. (2015). On the influence of the assortment concept on the performance of the shoe enterprises SFD and North Caucasus Federal District regions (Post 1). Scientific almanac, № 7 (9), pp. 740-753, 201.

6. Prokhorov, V. T., Aspen, T. M., Reva, D. V., Duyun, L. V., \& Zverev, S. M. (2015). On the influence of the assortment concept on the performance of the shoe enterprises SFD and North Caucasus Federal District regions (Post 2). Scientific almanac, № 7 (9), pp. 754-767.

7. Roar, D. V., Prohorov, V. T., Mishin, Y. D., Korablina, S. Y., Aspen, T. M., \& Tikhonov, N. (2016). What actions should be the most effective to their implementation provoked restore credibility to the domestic light industry. "New technologies and materials of light industry» XII International Scientific-practical conference with the elements of scientific school for students and young scientists: Collection of articles. (pp.45-52). Kazan: KNRTU.

8. Mishin, Y. D., et al. (2008). Quality Management competitive and sought-after materials and products: Monograph. Under the general editorship of prof. VT Prohorova (Eds.). (p.654). Mines: Publishing House of the GOU VPO "SRSUES".

9. Prohorov, V. T., et al. (2012). Production Management competitive and marketable products. Under the total. Ed. prof. VT Prokhorov (2012). VPO "SRSUES". (p.280). Novocherkassk: SRSTU (NPI).

10. Yevseyev, K. G., Davtyan, G., Prokhorov, V. T., Aspen, T. M., Tikhonov, N. V., \& Korablina, S. Y. (2016). The search for effective segmentation of the domestic market of the Southern Federal District and the North Caucasian Federal District in demand and competitive footwear. Leather and fur in the XXI century: technology, quality, ecology, education: Proceedings of the XII International Scientific and Practical Conference. (pp.312-320). Ulan-Ude: Publ VSGUTU.

11. Davtyan, G. G., et al. (2016). On the possibilities of assortment policy of import substitution in the regions of the Southern Federal District North Caucasus Federal District and competitive and marketable shoes. The integration of domestic science in the world: structural changes and future direction of development, 30-31 May 2016, St. Petersburg. (pp.65-69). SPb.: Publishing house "KultInformPress».

12. Davtyan, G., et al. (2016). Opportunities for import substitution concept assortment of products of lYe with gravesoftwood industrial regions of the SFD and North Caucasus Federal District // The integration of domestic science in the world: structural changes and future direction of development, 30-31 May 2016, St. Petersburg. (pp.69-76). SPb.: Publishing house "KultInformPress»».

13. Roar, D. V., Davtyan, G. G., Korablina, S. Y., Prohorov, V. T., Aspen, T. M., \& Tikhonov, N. 


\begin{tabular}{|c|c|c|c|c|c|c|}
\hline \multirow{4}{*}{ Impact Factor: } & ISRA (India) & $=3.117$ & SIS (USA) & $=0.912$ & ICV (Poland) & $=6.630$ \\
\hline & ISI (Dubai, UAE & $=0.829$ & РИНЦ (Russia & $=0.156$ & PIF (India) & $=1.940$ \\
\hline & GIF (Australia) & $=0.564$ & ESJI (KZ) & $=8.716$ & IBI (India) & $=4.260$ \\
\hline & JIF & $=1.500$ & SJIF (Morocce & $=5.667$ & OAJI (USA) & $=0.350$ \\
\hline
\end{tabular}

(2016). On the possibility of randomization for reasonable segmentation of national markets and regions of the Southern Federal District North Caucasus Federal District of children's shoes. Leather and fur in the XXI century: technology, quality, ecology, education: Proceedings of the XII International Scientific and Practical Conference. (pp.327-335). UlanUde: Publ. VSGUTU.

14. Reva, D. V., Davtyan, G. G., Korablina, S. Y., Prokhorov, V. T., Aspen, T. M., \& Tikhonov, N. V. (2016). On the influence assortment policy and innovative solutions for the production of import of footwear for consumers in the region SFD and North Caucasus Federal District. Leather and fur in the XXI century: technology, quality, ecology, education: Proceedings of the XII International scientific and practical conference. (p.374). Ulan-Ude: Publ VSGUTU.

15. Reva, D. V., Davtyan, G. G., Korablina, S. Y., Prokhorov, V. T., Aspen, T. M., \& Tikhonov, N. V. (2016). Features assortment policy of market segmentation SFD and North Caucasus Federal District of import-substituting footwear for consumers. Leather and fur in the XXI century: technology, quality, ecology, education: Proceedings of the XII International scientific and practical conference. (pp.390-397). UlanUde: Publ VSGUTU.

16. Zagrebel'nyi, S. O., Prokhorov, V. T., Aspen, T. M., Korablina, S. Y., Volkova, G. Y., \& Tikhonov, N. (2016). On the possibilities of innovative solutions for enterprises import substitution product lYe with gravesoftwood industrial regions of the SFD and North Caucasus Federal District. The integration of domestic science in the world: structural changes and future direction of development, 30-31 May 2016, St. Petersburg. (p.107-114). SPb.: Publishing house "KultInformPress».

17. Zagrebel'nyi, S. O., Prokhorov, V. T., Aspen, T. M., Korablina, S. Y., Volkova, G. Y., \& Tikhonov, N. (2016). On peculiarities of formation of competitiveness of production of the SFD and North Caucasus Federal District based on the concept of regional partnership. The integration of domestic science in the world: structural changes and future direction of development, 30-31 May 2016, St. Petersburg. (pp.114-123). SPb.: Publishing house "KultInformPress»».

18. Getmanova, E. F., Korablina, S. Y., Prokhorov, V. T., Aspen, T. M., \& Tikhonov, N. V. (2016). IS Import substitution Shrayfel shoe due to an informed decision assortment policy with a view to ensuring consumer demand shoes. II International scientific-practical conference "Models of innovative development of the textile and light industry on the basis of the integration of university science and industry. EducationScience-Production ": a collection of articles. March 23-25, 2016.; $M$ of the image. and Science of Russia, Kazan. nat. issled. tehnol. Univ. (pp.335-341). Kazan: Publishing house KNRTU.

19. Evseev, K. G., Korablina, S. Y., Prokhorov, V. T., Rezvanova, L. N., \& Tikhonov, N. (2016). On the benefits of innovative technologies for segmenting markets competitive and popular shoe. II International scientific-practical conference "models of innovation development of textile and light industry on the basis of the integration of university science and industry. Education-Science-Production ": a collection of articles. March 23-25, 2016.; M of the image. and Science of Russia, Kazan. nat. issled. tehnol. Univ. (pp.341-349). Kazan: Publishing house KNRTU.

20. Prohorov, V. T., et al. (2017). The concept andmportozamescheniya light industry: background, objectives, innovations. monograph / under the total. Ed. Dr. tehn. Sciences, prof. VT Prokhorov (Eds.). Institute of Entrepreneurship and Service sector (branch) of the Don State Technical university. (p.334). Mines: ISOiP (branch) of Dagestan State Technical University. 